Chapter 22

\title{
Importance of Extracellular Environment for Regenerative Medicine and Tissue Engineering of Cartilagious Tissue
}

\author{
Shigeru Kobayashi \\ Additional information is available at the end of the chapter \\ http://dx.doi.org/10.5772/55566
}

\section{Introduction}

Cartilage degeneration caused by osteoarthritis (OA) and trauma is of great clinical consequence, given the limited intrinsic healing potential of the cartilaginous tissue. OA is the most common joint disease in world populations. Pain during activities of daily living is a common presenting complaint of individuals with $\mathrm{OA}$ and is also associated with a decrease in quality of life for people with OA. Its incidence increases with age, and thus this degenerative disease is a major problem in ageing populations. OA is a multifactorial disease of the joints characterized by gradual loss of articular cartilage. In the recent years, the mechanism of chondrocyte differentiation has come to be well understood owing to the advancement of molecular biology, and researches have rapidly progressed for bioengineering or tissue engineering technique, where it is aimed to regenerate/reconstruct tissues by simulating the process of cell or tissue differentiation during development. Articular cartilage is composed mainly of collagen/proteoglycan (PG) and water. PG accounts for about 7 - 10\% of cartilage tissues, and aggrecan, which is a member of PG representing macromolecules, plays a key role for mitigation of mechanical stress imposed on the cartilage tissues (Maroudas, 1979). A fall in PG concentration is one of the first changes in OA with consequent deleterious effects on the mechanical behaviour of cartilaginous tissues (McDevitt \& Muir, 1976, Venn \& Maroudas 1977). Among the components of aggrecan, negatively-charged Glycosaminoglycan (GAG) produces a high osmotic pressure in the cartilage tissue, and water is therefore absorbed in the cartilage tissues. As a result, the collagen networks are inflated, and the cartilage tissues acquire elastic resistance characteristic to cartilage tissues to protect from compression force. Thus, the 
strength of cartilage tissues strongly depends on the density of aggrecan (Kempson et al., 1970, Maroudas, 1979, Maroudas \& Bannon 1981). Therefore, in order to produce cartilage tissues that can tolerate mechanical force of about 10-20 Mpa using the tissue engineering technology, it is necessary to generate sufficient PG (Hodge et al., 1986). PG/GAG generation depends on the amount of GAG production, the capacity of GAG retention in the tissues, and the concentration of cells (Kobayashi et al., 2008). There is now an increasing interest in developing biological methods of cartilage repair for these disorders with attainment of the correct biomechanical properties critical for success (Brittberg et al. 1994, Minas, 2001, Risbud \& Sittinger 2002, Schaefer et al. 2002 Ochi et al. 2002, Robert et al. 2003). The stiffness of cartilaginous tissues is thus strongly dependent on aggrecan content. Therefore, one of the targets of successful repair is thus that GAG concentration of the tissue-engineered construct should approach that of the native cartilage. First of all, it is important to establish the optimum culture conditions for the generation of cartilaginous tissues. In this study, we examined how physiological levels of extracellular osmolality and cell density influence PG accumulation in chondrocytes in a three-dimensional culture system. And also, we evaluated the influence of transforming growth factor- $\beta$ (TGF- $\beta$ ) and fibroblast growth factor-2 (FGF-2), which are involved on the metabolism of PGs by cartilage cells cultured under low-osmotic conditions.

\section{Changes of the extracellular environment in the articular cartilage with age}

Unlike other connective tissues, articular cartilage represents avascular tissue. The chondrocytes may receive nutrients via the vascular system under subchondral bone as well as via the synovial fluid and are supplied by diffusion, helped by the pumping action generated by compression of the articular cartilage or flexion of the elastic cartilage (Brower, et al. 1962, Mankin 1963, Maroudas, et al. 1968, Hodge \& McKibbin 1969, McKibbin \& Holdsworth 1966, O'Hara et al. 1990). Nutritional supply to the cartilaginous tissue is affected by the architecture of the vascular system and the porosity in the subchondral bone (Fig.1A). Nutrients move from the vascular systems under subchondral bone that supply the cartilaginous tissue, through the subchondral bone and the dense matrix of the cartilaginous tissue, to the chondrocytes. Its limits transport of large molecules into and out of the cartilaginous tissue. For small solutes such as glucose, lactate acid, and oxygen, both experimental and modeling studies have shown that solute transport is accomplished mainly by diffusion (Mauck et al. 2003a), hence, the movement of fluid in and out of the cartilaginous tissue as a result of the diurnal loading pattern has little direct influence on transport. Gradients in the concentration arise depending on the balance between the rate of supply of glucose or oxygen from the blood supply to the cells and the rate of cellular consumption (Stockwell, 1991, Hall, et al. 1993, Lee \& Urban, 1997, 2002). 
The cartilaginous tissue is avascular, and the metabolic activity of its cells is regulated by various factors in the extracellular matrix, such as oxygen concentration (Lane et al, 1977, Lee \& Urban, 1997, 2002), extracellular osmolality (Urban \& Bayliss, 1989, Urban et al., 1993, Bush \& Hall, 2001, Palmer et al., 2001, Erickson et al., 2001, Bush et al., 2005, Negoro, et al., 2008), pH (Wilkins \& Hall, 1995, Gray et al.,1988), mechanical stress (Gray et al. 1989, Urban 1994, 2000), and various growth factors (Morales \& Roberts, 1988, Luyten et al, 1988, Morales, 1994, Van Osch, et al. 1998, Huck, 2001). The cell density of the normal human cartilaginous tissue is $2-4 \times 10^{6}$ cells $/ \mathrm{mL}$, and the extracellular environment differs markedly from that of other tissues, with an oxygen saturation of $1-6 \%$, $\mathrm{pH}$ of $6.8-7.1$, and extracellular osmolality of 350-450mOsm. So, the cartilaginous extracellular environment is relatively hypoxic, unlike the case of other tissues. And also, the articular chondrocytes are exposed to a unique osmotic environment, which varies throughout the depth of cartilage, and in response to mechanical loading or pathological conditions. It is said that such a harsh environment suppresses chondrocyte differentiation and maintains the nature characteristic to chondrocytes. Thus, compared to other connective tissues, cartilage grows and repairs more slowly.

The articular cartilage is essential for absorbing shock and maintaining normal joint environment, and, regardless of the cause, degeneration of articular cartilage can result in irreversible osteoarthritis. Osteoarthritis is commonly referred to as wear-and-tear arthritis. There are other parts of joint anatomy, like subchondral bone, that play a significant role in osteoarthritis. Subchondral bone is the layer of bone just below the cartilage. The subchondral bone does not normally provide a barrier to diffusion. In aging and degeneration, however, the subchondral bone tends to calcify by unknown mechanisms and the apparent permeability of this plate decreases with age, as the subchondral bone becomes more sclerotic (Lane, et al., 1977, Lane, \& Villacin, 1980, Botter et al., 2011). The consequent fall in supply of nutrients to the chondrocytes inhibits their ability to synthesize and maintain the matrix and even leads to cell death (Kühn, 2004). In osteoarthritis, subchondral bone becomes thicker than usual (Fig1B). Adult hyaline articular cartilage is progressively mineralized at the junction between cartilage and bone. It is then termed articular calcified cartilage. A mineralization front advances through the base of the hyaline articular cartilage at a rate dependent on cartilage load and shear stress. Intermittent variations in the rate of advance and mineral deposition density of the mineralizing front, lead to multiple "tidemarks" in the articular calcified cartilage. Adult articular calcified cartilage is penetrated by vascular buds, and new bone produced in the vascular space in a process similar to endochondral ossification at the physis. A cement line demarcates articular calcified cartilage from subchondral bone. Vascular channels connect the marrow spaces of trabecular bone with the calcified cartilage layer, thus nourishing the deeper cartilage layers that cannot be nourished by synovial fluid (Duncan, 1987, Milz \& Putz, 1994). These vascular channels also nourish osteocytes in the subchondral bone plate, unlike osteocytes in trabecular bone, which receive nourishment from marrow tissue. In aging, however, the subchondral bone tends to calcify by unknown mechanisms (Fig.9B). This tide mark (calcification) acts as a barrier to nutrients transport and is thought to be a major factor in the development of osteoarthritis. Cellular parameters are very important in regulating nutrient 
levels, with levels of oxygen or $\mathrm{pH}$ falling with increases in rates of cell metabolism or cell density. For the chondrocytes to remain viable, the levels of extracellular nutrients and $\mathrm{pH}$ must remain above critical values. Because disc cells obtain ATP primarily by glycolysis, glucose is a critical nutrient. The cells start to die within twenty-four hours if glucose concentration falls below $0.2 \mathrm{mM}$ and the efficiency of glucose transport into the cell is likely reduced at this glucose concentration (Windhaber et al., 2003). The rate of cell death increases when $\mathrm{pH}$ levels are acidic. The cell viability is reduced even with adequate glucose at $\mathrm{pH}$ 6.0. The osmotic environment of chondrocytes in the articular cartilage changes with loading and pathologic states. The osmolality of the extracellular matrix is regulated by negatively charging the GAG chains of PGs which adjust ionic composition. Particularly, extracellular osmolality is controlled by negatively charged PGs. It is now evident that an increase in the concentration of PGs which control ionic composition causes an increase in the osmolality, and conversely, a decrease in PGs reduces osmolality (Maroudas, 1981). Maroundas et al. (1975) investigated the osmotic pressures in articular sections extending to the sagittal sections and reported that the osmotic pressure in the articular cartilage is about 370-400 mOsm and were decreased in the degenerated articular cartilage. Thus, it may be said that osmotic pressure gradient disturbance associated with reduced PGs is an important factor contributing to the development of disc degeneration. The results also suggest that standard culture mediums do not provide an appropriate ionic and osmotic environment for chondrocytes.

The physico-chemical environment created and maintained by chondrocytes in turn has a powerful effect on cartilaginous metabolism. However, the supply of nutrients from vascular systems at the subchondral bone to the cartilaginous tissue of osteoarthritis is likely to be affected, causing the extracellular environment to deteriorate and some cells in degenerate cartilage are senescent (Kühn, 2004). This environment is often neglected by it can strongly influence matrix turnover or the responses of chondrocytes to growth factors or other external stimuli. Such limitations apply to all avascular tissues including tissue engineered constructs.

\section{Effect of extracellular osmolality on glycosaminoglycan production and cell metabolism with time in culture}

The effect of change in extracellular osmotic pressure on the amount of GAG production has not been well understood. It is important to initially know what culture condition provides the optimal environment for generation of articular cartilage. Therefore, we conducted an in vitro study to investigate the effects of change in extracellular osmotic pressure on cartilage cell morphology, GAG production, and cartilage cell metabolism, using the alginate beads system for three-dimensional culture of articular chondrocytes (Negoro, et al., 2008). Cells were obtained from metacarpal phalangeal joints of 18-24 month bovine. They were cultured for 6 days in alginate beads at 4 million cells/ml in DMEM containing 6\% FBS under $21 \% \mathrm{O}_{2}$, Medium osmolality was altered by $\mathrm{NaCl}$ addition over the range $270-570 \mathrm{mOsm}$ and monitored using a freezing point osmometer. 
A. NORMAL

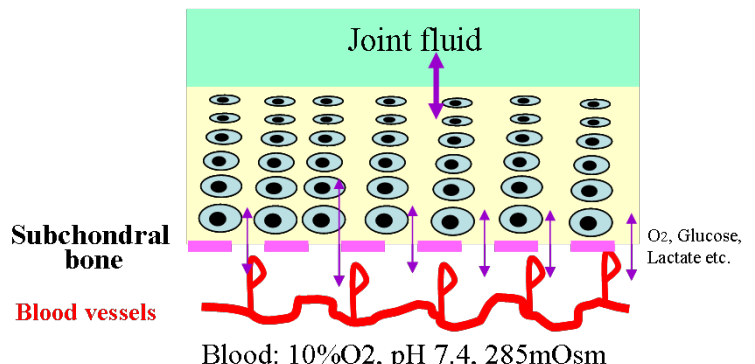

Blood: $10 \% \mathrm{O} 2, \mathrm{pH} 7.4,285 \mathrm{mOsm}$

\section{B. OSTEOARTHRITIS (OA)}

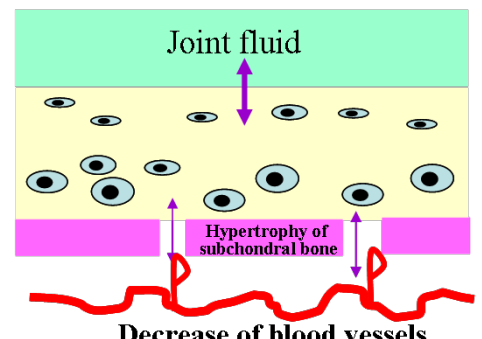

Decrease of blood vessels

Figure 1. Changes of nutrient supply rote and extracellular environment of cartilaginous tissue with aging. (A) Normal cartilaginous tissue, (B) Osteoarthritis (OA).(A) This schema shows a representation of healthy articular cartilage overlying the subchondral trabecular bone. Although chondrocytes occupy less than $1 \%$ of articular cartilage, they are responsible for maintaining the integrity of the extracellular matrix by balancing macromolecular synthesis with breakdown. The matrix that surrounds them confers a mechanically resilient surface to the articulating bones within joints, and comprises collagens (principally collagen II), other noncollagenous proteins, and proteoglycans. In addition to structural support and absorption of shock offered by the subchondral bone, its small vessels and probably the interstitial bone fluid in osteocyte canaliculi, provide important nutrition to the cartilage. (B) The right schema shows some cartilage erosion, as seen in OA. The number of chondrocytes decreases with aging, but it is unknown whether this decline is caused by apoptosis, or insufficient supply of nutrients from the end plate. Ossification of the subchondral bone (tide mark) occurs with aging and is one of the major causes of cartilaginous degeneration. This leads to deterioration of the extracellular environment in the cartilaginous tissue and causes cellular impairment that is followed by a decline of matrix metabolism, resulting in progression to osteoarthritis. The nutrient supply for cells and the extracellular environment of the cartilaginous tissue have a considerable influence on the outcome of treating osteoarthritis by bioengineering techniques.

\subsection{Cell viability}

After 2, 4 and 6 days of culture, the chondrocyte viability rate was $90 \%$ or higher in all of the 4 osmolality groups (Fig.2). So, chondrocyte viability was not modified by the difference in extracellular osmolality. However, confocal microscopy showed that the cells were the largest under 270 mOsm and became smaller with increasing osmotic pressure (Fig.3). Under transmission electron micrographs of chondrocytes, at 370 and 470 mOsm all cells appeared viable, with large nuclei, dotted with chromatin and abundant rough endoplasmic reticulum (Fig.4B, C). The cells appeared active throughout the beads. In the beads cultured at 270mOsm, however, all cells were swelling with numerous cytoplasmic vacuoles and lipid droplets (Fig. 4A). Many cells had blebbing and these cells undergoing oncosis were seen. Under 570mOsm, many cells were reduced in size and blebbing was visible in the nuclei (Fig 4D,5A,5B).

\subsection{GAG production and cell metabolism}

Osmotic environment of cells in cartilage tissues is altered significantly by loading and morbid conditions. The cartilage tissues sustain static load and prolonged cyclical loading all the time 


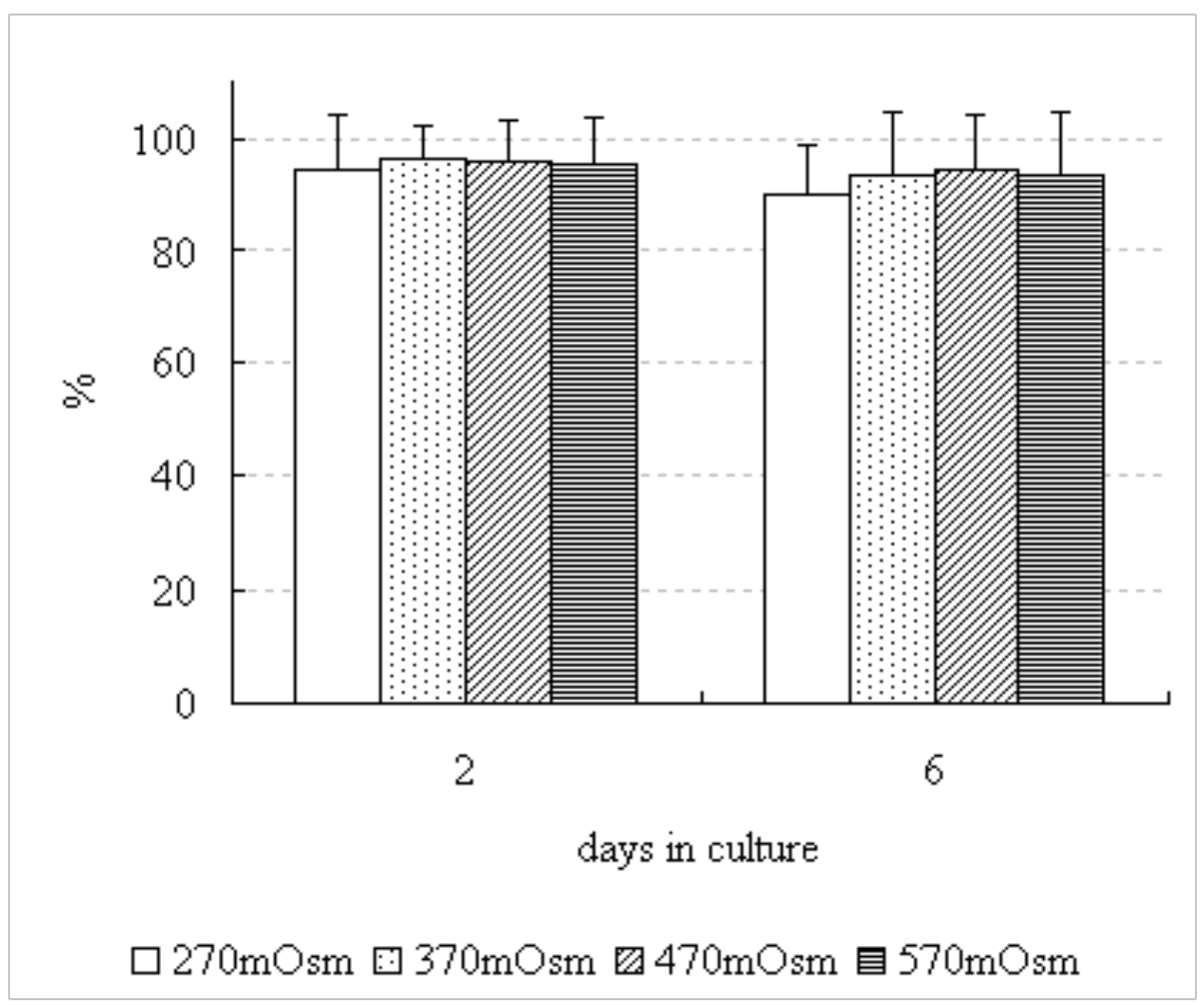

Figure 2. The cell viability by manual counting using a Live/Dead assay kit containing fluorescent probes. After 6 days of culture, the survival rate of cells was $90.3 \pm 8.7,93.3 \pm 11.5,94.4 \pm 9.6$, and $93.3 \pm 11.5 \%$ (mean \pm SEM) respectively in the $270,370,470$, and 570 mOsm groups. The percentage of live and dead cells in sections was similar for the high and low osmolality cultures.

and osmolality imbalance occurs in the articular cartilage. To overcome osmotic imbalance and acquire new equilibrium, fluid is exuded from the tissue, and the PG level, cation level, and osmotic pressure are increased as a result. The chondrocytes always sustains high osmotic pressure. When loading is removed the tissue, fluid is slowly absorbed in turn, and the normal osmotic status is recovered. Urban, et al. (1993) incubated chondrocytes isolated from the articular cartilage in commercially- available DMEM solutions set at 250-270 mOsm of osmolality for 2 hours. Their experiment showed that the chondrocytes swelled by about $30-40 \%$ in the above osmolality condition and chondrocytes incubated in a medium set at $350-400$ mOsm for osmolarity were most close to the size of chondrocytes in the intact tissues and synthesized the highest amount of PG. Hopewell \& Urban (2003) investigated the effect of extracellular osmolality on chondrocytes cultured in alginate beads. Their study showed decreased sulphate incorporation rate for the cells incubated at high osmolality for 4 hours, recovery of sulphate incorporation rate for the cells incubated at high osmolality for 24 and 48 hours, and a higher sulphate incorporation rate than the original level for the cells incubated 

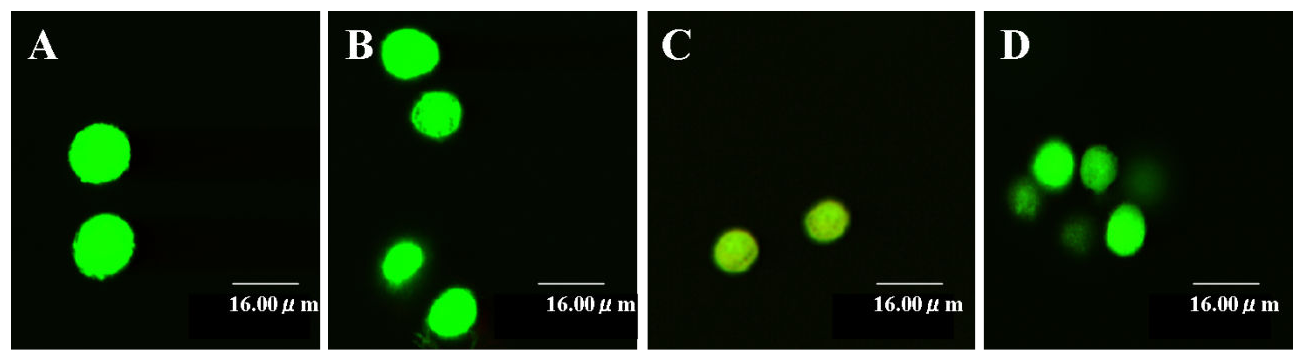

$\mathbf{E}$
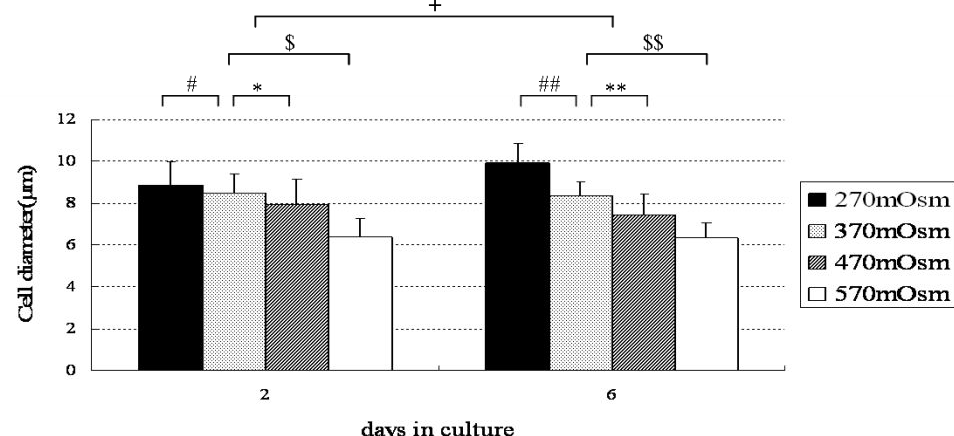

圆 $370 \mathrm{mOsm}$ VIA $470 \mathrm{mOsm}$ $\square 570 \mathrm{mOsm}$

Figure 3. Confocal microscopy showed that the chondrocytes were greatest in the 270 mOsm group and diminished gradually along with the increases in osmolality. The diameters of cells measured obviously decreased in the higher osmolality groups $(P<0.05)$. After 6 days of culture, the chondrocyte diameter was $9.9 \pm 0.9,8.4 \pm 0.6,7.4 \pm 0.9$, and $6.3 \pm 0.8 \mu \mathrm{m}$ (mean \pm SEM) respectively in the $270,370,470$, and 570 mOsm groups. The cell diameter was already established by 2 days of culture. The cell diameter increase with time in culture $(P<0.05)$. (Reproduced with permission from Negoro K, Kobayashi S, et al. Effect of osmolality on glycosaminoglycan production and cell metabolism of articular chondrocyte under three dimensional culture system. Clin Exp Rheumatol 26: 527-533,2008.)

further. Based on these results, they indicated that chondrocytes are sensitive to osmolality and are able to adjust for high osmolality during short time. Bush, et al (2005). reported a single impact caused temporal and spatial changes to in situ chondrocyte viability with cell shrinkage occurring in the majority of cells. However, chondrocyte shrinkage by raising medium osmolality at the time of impact protected the cells from injury, whereas swollen chondrocytes were markedly more sensitive. These data showed that chondrocyte volume could be an important determinant of the sensitivity and response of in situ chondrocytes to mechanical stress. And also, Erickson, et al (2001). indicated that osmotic stress causes significant volume change in chondrocytes and may activate an intracellular second messenger signal by inducing transient increases in intracellular calcium ion. Palmer, et al (2001). measured the aggrecan promoter activity and mRNA levels using bovine monolayer chondrocytes subjected to hyperosmotic loading for different time periods from 1 minute to 24 hours. They concluded the hyper-osmotic loading regulates aggrecan gene expression and cell size in isolated. Thus, mechanical compression of cartilage is associated with a rise in the interstitial osmotic pressure, which can alter cell volume and activate volume recovery pathways. 

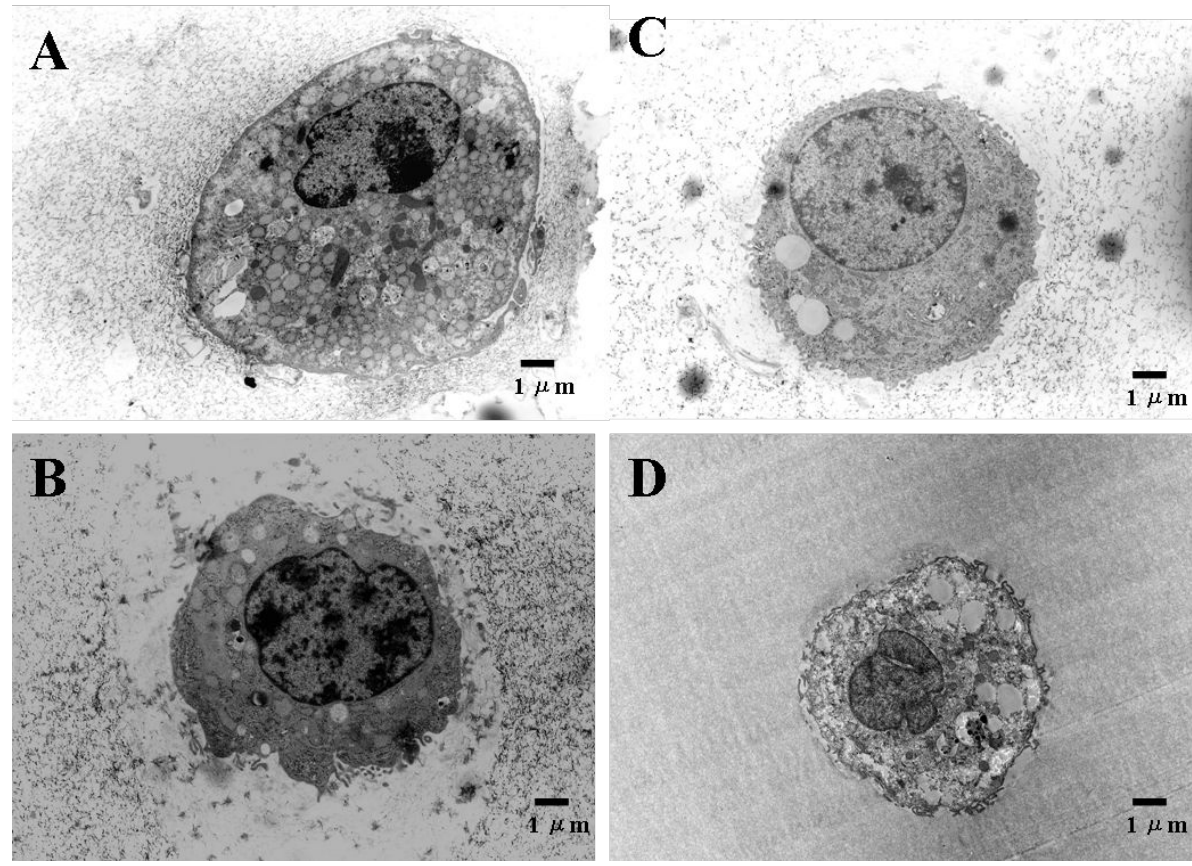

Figure 4. Electron micrograms of nucleus pulposus cells in the centre of the beads.A. under 270mOsm, B. under $370 \mathrm{mOsm}, \mathrm{C}$. under $470 \mathrm{mOsm}$, D. under $570 \mathrm{mOsm}$.At $270 \mathrm{mOsm}$, the cell was swelling with numerous vacuoles and cytoplasmic organelles destroyed were visible. This cell undergoing oncosis were seen. At 370 and $470 \mathrm{mOsm}$, all cells appeared viable. At $570 \mathrm{mOsm}$, the cell and nuclei was reduced in size and chromatin condensation was visible in the nuclei. (Reproduced with permission from Negoro K, Kobayashi S, et al. Effect of osmolality on glycosaminoglycan production and cell metabolism of articular chondrocyte under three dimensional culture system. Clin Exp Rheumatol 26: 527-533,2008.)

In our study, GAG accumulation was measured using a modified dimethylmethylene blue (DMB) assay. GAG production was largest in the $370 \mathrm{mOsm}$, and the capacity for GAG production and cell metabolism (lactate production) was low under hypo-osmolality and hyper-osmolality, and cell deaths were often observed on electron microscopy. While total GAG in beads/ $\mathrm{ml}$ of beads volume increased with the duration of culture, it was greatest in the 370 mOsm group and lowest in the 270 mOsm group during culture (Fig.6A). The total GAG in beads/ml of beads volume was greatest in the 370 mOsm group, being $0.298 \pm 0.035$ $($ mean \pm SEM) $\mathrm{mg} / \mathrm{ml}$ at day 6 . It was lowest in the $270 \mathrm{mOsm}$ group than in the other osmolality groups, being $0.122 \pm 0.019 \mathrm{mg} / \mathrm{ml}$. In the high osmolality group at $570 \mathrm{mOsm}$, the total GAG in beads $/ \mathrm{ml}$ of beads volume was greater than that in the 370 and 470 mOsm group after 2 days of culture, while the percentage of increased diminished subsequently until day 6. Similarly the rate of GAG in beads per live cell was the highest in the 370 mOsm group during culture (Fig.6B). While the total GAG in beads/million cells increased with the duration of culture, it was greatest in the 370 mOsm group and lowest in the 270 mOsm group during up to 6 days of culture. In the high osmolarity group at $570 \mathrm{mOsm}$, the total GAG in beads/million cells was 


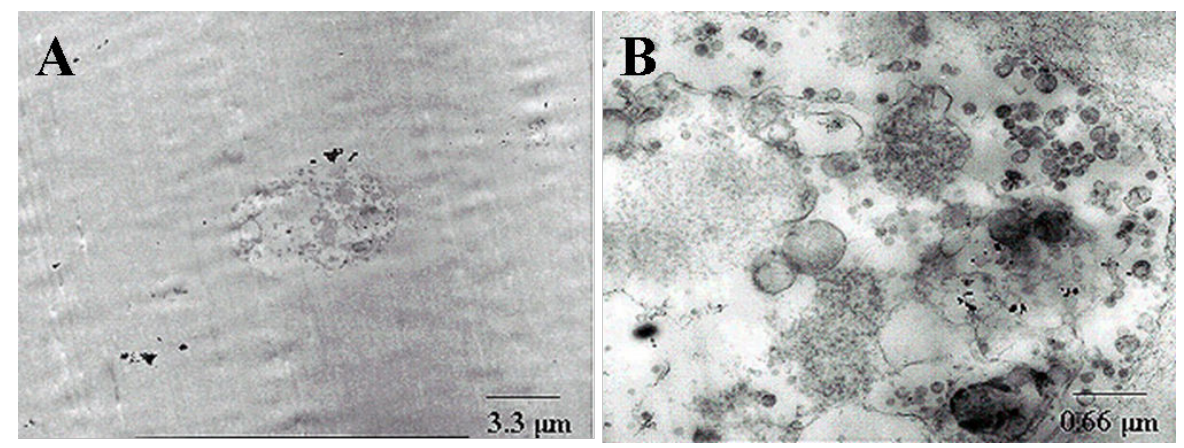

Figure 5. Under 570mOsm, Some cells undergoing apoptosis were seen. Cells with condensed and fragmented nuclei and condensed chromatin (apoptotic bodies) and with cytoplasmic organelles destroyed were visible. (Reproduced with permission from Negoro K, Kobayashi S, et al. Effect of osmolarity on glycosaminoglycan production and cell metabolism of articular chondrocyte under three dimensional culture system. Clin Exp Rheumatol 26: 527-533, 2008).

greater than that in the 270 mOsm group after 2 days of culture, while the percentage of increased diminished subsequently until day 6 . The cell cultured at 370 and $470 \mathrm{mOsm}$ were thus more active and accumulated significantly more GAG than cells cultured at 270 and 570 mOsm with time. In this study, the cells incubated at $370 \mathrm{mOsm}$ produced the greater amount of GAG, and the cells incubated at high osmolality for 2 days showed a similar trend for GAG production to the results of Hopewell's experiment (2003) using isolated articular cartilage. However, the cells incubated further for 6 days produced a lower amount of GAG in the condition of high osmolarity and showed the profile of cell death (apoptosis) under electron microscope. Thus, this study indicates that chondrocytes is unable to adjust for such nonphysiological conditions lasting for a long time and this phenomenon plays a critical role in the development of cartilage degeneration and resultant OA.

The lactate production was measured enzymatically and the rate of sulphate GAG synthesis was measured using a standard ${ }^{35} \mathrm{~S}$-sulphate radioactive method. Fig.7A shows the effect of extracellular osmolalities on lactate production by chondrocytes, a marker for total energy production. The rate of lactate production per live cell significantly decreased with time in culture. Lactate production was significantly decreased in hypo-osmolality ( $270 \mathrm{mOsm}$ ) group compared with the other groups. Thus, cell metabolism was decreased with the duration of culture, but metabolic hypofunction persisted under hypo-osmolality. Similarly the rate of sulphate incorporation per live cell was the highest in the 370 mOsm group during culture, and was decreased with an increase in extracellular osmolality (Fig. 7B). It was the lowest in the hypo-osmolality ( $270 \mathrm{mOsm}$ ) group during culture. The cells cultured at 370 and $470 \mathrm{mOsm}$ were more active significantly more sulphate incorporation per live cell than cells cultured at 270 and $570 \mathrm{mOsm}$. The rate of sulphate incorporation fell more steeply than lactate rates with time in culture. 


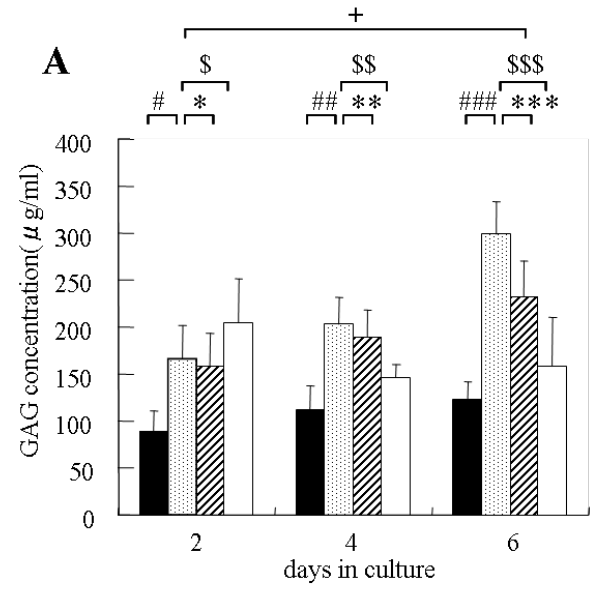

$270 \mathrm{mOsm}$ 370mOsm $\square 470 \mathrm{mOsm} \square 570 \mathrm{mOsm}$

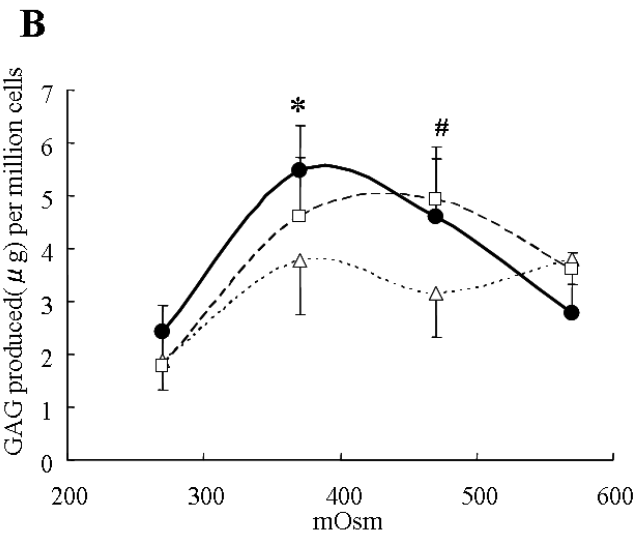

$\triangle$ day2 - $\square-$ day4 $\longrightarrow$ day 6

Figure 6. Effect of extracelluler osmotic change on GAG accumulation/tissue volume (A) and GAG produced per million cells (B). This figure gives pooled data for 4 representative osmolality from 3 separate experiments for cells cultured by articular chondrocytes. (A) GAG accumulation/tissue volume was significantly increased at 370 and 470 mOsm with time in culture. This was the highest in the $370 \mathrm{mOsm}$ group and the lowest in the hypo-osmolality group ( $270 \mathrm{mOsm}$ ) decreased after 6 days of culture. In the hyper-osmolality group ( $570 \mathrm{mOsm}$ ), the rate of GAG accumulation/tissue volume wasn't decreased after 2 days of culture when compared with the 370 mOsm group. Values are mean \pm standard error. (Scheffe, ${ }^{*}: P<0.05$ ). (B) GAG produced per million cells was significantly increased at 370 and 470 mOsm with time in culture $\left({ }^{*}, \#: \mathrm{P}<0.05\right.$, Scheffe between between 2 and 6 days)] This was the highest in the 370 mOsm group and the lowest in the hypo-osmolality group ( $270 \mathrm{mOsm})$ decreased after 6 days of culture. In the hyperosmolality group (470 and 570 mOsm), the rate of total GAG produced per million cells wasn't decreased after 2 days of culture when compared with the 370 mOsm group. (Reproduced with permission from Negoro K, Kobayashi S, et al. Effect of osmolarity on glycosaminoglycan production and cell metabolism of articular chondrocyte under three dimensional culture system. Clin Exp Rheumatol 26: 527-533,2008).

In this study, the chondrocytes produced the highest amount of GAG in the osmolality condition of 370 mOsm after 2 and 6 days of culture. The amount of GAG production was obviously lower in the low osmolality cultures than in the culture at the optimal osmolarity close to that in the normal cartilage. On electron microscopy of chondrocytes cultured under varying levels of osmolality, cells under 370 mOsm generally showed normal nuclei and cytoplasm, while cells under hypo-osmolality presented oncotic changes, with cellular swelling and destructed organelles of the cytoplasm. On the other hand, cells cultured under hyper-osmolality were reduced in size and some cells underwent apoptosis. Manjo \& Joris (1995) reported oncosis is a form of cell death accompanied by cellular swelling, organelle swelling, blebbing, and increase membrane permeability. They also showed that necrosis can occur after both forms (oncosis and apoptosis) of cell death. Therefore, its mechanism is based on failure of the ionic pumps of the plasma membrane induced by the changes of extracellular osmotic environment. Thus, our physiological and morphological study showed the articular chondrocytes is unable to adjust for such non-physiological conditions lasting for a long time and this phenomenon plays a critical role in the development of cartilage degeneration and resultant OA. 

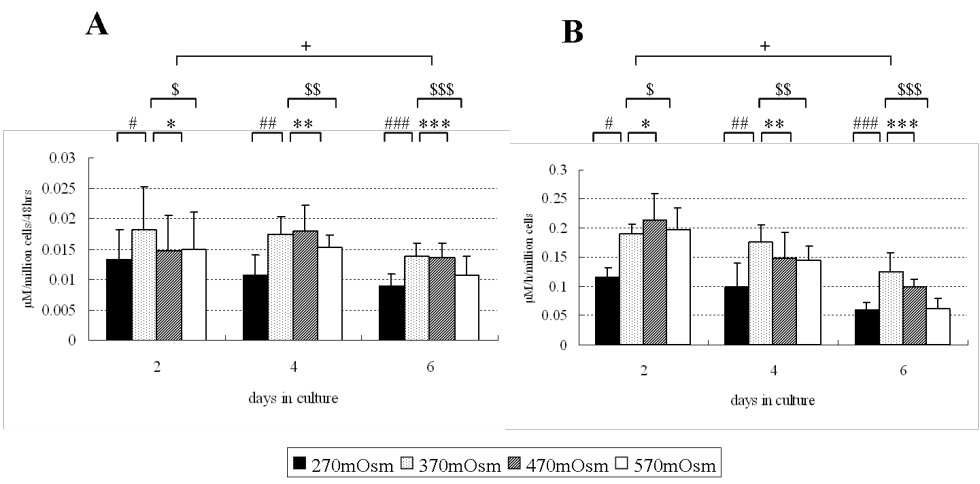

Figure 7. Effect of extracellular osmotic change on lactate production rate $(A)$ and ${ }^{35} \mathrm{~S}$-sulphate incorporation rate (B). (A) The rate of lactate production per live cell decreased with time in culture $(+: P<0.05,2$ way ANOVA with repeated measures among 2,4 and 6 days). After 4 and 6 days of culture, lactate production was clearly decreased under hypoosmolality (270 mOsm) compared with other levels of osmolality. (Scheffe between 270 and $370 \mathrm{mOsm}$ [\#: P=0.405, \#\#,\#\#: $\mathrm{P}<0.05], 370$ and 470 mOsm [*: $\mathrm{P}=0.707,{ }^{* *}: \mathrm{P}=0.988$, $\left.{ }^{* * *}: \mathrm{P}=0.997\right]$, or 370 and 570 mOsm [\$: $\mathrm{P}=0.738, \$ \$$ : $P=0.559, \$ \$: P=0.083])$. (B) Sulphate incorporation rates fall with time in culture $(+: P<0.05,2$ way ANOVA with repeated measures among 2,4 and 6 days). Values are mean \pm standard error. It was clearly decreased in the hypo-osmolality (270 mOsm) groups compared with the 370 mOsm groups during culture. After 6 days of culture, lactate production was clearly decreased under the 570 mOsm groups compared with the 370 mOsm groups. (Scheffe between 270 and 370 mOsm [\#,\#\#,\#\#: $P<0.05], 370$ and 470 mOsm [*: $\left.P=0.537,{ }^{* *}: P=0.446,{ }^{* * *}: P=0.109\right], 370$ and 570 mOsm [\$: $P=0.98, \$: P=0.366, \$ \$: P<0.05]$ ). (Reproduced with permission from Negoro K, Kobayashi $S$, et al. Effect of osmolarity on glycosaminoglycan production and cell metabolism of articular chondrocyte under three dimensional culture system. Clin Exp Rheumatol 26: 527-533,2008).

The osmotic pressure in the cartilage tissues is obviously higher than the plasma osmolarity (about $280 \mathrm{mOsm}$ ), and chondrocytes exist in the extracellular environment different from that of other tissues. This study indicated that adjustment of osmolality is very important for the culture of chondrocytes. At cell densities found in vivo (standard conditions) in the cartilage tissue viz, 4 million cells $/ \mathrm{ml}$ and GAG concentration in beads cultures was $0.298 \mathrm{mg} / \mathrm{ml}$ at 370 mOsm in 6 days. Assuming that the initial production rate is maintained and that there is no loss of GAG, it is calculated that $>1000$ days of culture is necessary to produce a GAG concentration equal to the in vivo GAG concentration of $7 \%$ per wet weight (viz. $70 \mathrm{mg} / \mathrm{ml}$ ). That is, it is suggested that chondrocytes need to be cultivated at the cell density of $4 \times 106$ cells $/ \mathrm{ml}$ for more than 1 year in order to construct cartilage tissue in the GAG concentration of about 70 - $100 \mathrm{mgs} / \mathrm{ml}$, which is equal to the GAG concentration in the normal cartilage tissues, using cell culture technology.

\section{Effect of growth factor on glycosaminoglycan production in articular chondrocytes}

Growth factors, such as transforming growth factor- $\beta$ (TGF- $\beta$ ) and fibroblast growth factor- 2 (FGF-2), have demonstrated a great potential as cartilage anabolic factors because of their 
ability to induce matrix synthesis and promote repair in cartilage. TGF- $\beta$ is one of the anabolic factors involved in cartilage maintenance and appears to be a good candidate for cartilage repair. TGF- $\beta$ is a stimulator of extracellular matrix production, like collagen type II and proteoglycan (PG), in chondrocytes and it downregulates matrix-degrading enzymes (Edwards, et al. 1987). High amounts of TGF- $\beta$ are stored in healthy cartilage (Pedrozo, et al. 1998, Redini F, et al. 1997, Morales, et al. 1991a,b, Burton-Wurster \& Lust,1990), whereas in OA cartilage the expression of TGF- $\beta$ is reduced (Verdier et al. 2003). FGF-2 belongs to the family of heparin-binding growth factors (Gospodarowicz, et al. 1987). This proteins are known to induce chemotactic, angiogenic, and mitogenic activity, and play an important role in early differentiation and development (Powers et al., 2000, Burgess \& Maciag, 1989). Cell expansion in the presence of FGF-2 was shown to promote differentiation of stromal cells into cartilaginous tissues (Martin, et al. 1998). Similary, FGF-2 was shown to retain the chondrogenic differentiation potential of extensively expanded stromal cells (Tsutsumi, et al. 2001). Like wise, pellet cultures established from FGF-2 treated human mesenchymal stem cells were larger in size and contained a higher level of proteoglycans than untreated cells (Solchaga, et al. 2005). Martin et al. (1999a, 2001) showed that the FGF-2 treatment increased cell number during monolayer expansion and the differentiation capacity of expanded chondrocytes in subsequent 3-dimensional culture.

The most important problems in cartilage regeneration medicine are to supply nutrients to cells activated by grafting or growth factors and to maintain a healthy extracellular environment. However, it has been shown that the extracellular osmotic pressure decreases with cartilage degeneration in candidates for treatment. In this study, cells were isolated from the cartilage from metacarpal phalangeal joints of 18-24 month bovine. Alginate beads containing cartilage cells collected from adult bovine ( 4 million cells $/ \mathrm{ml}$ ) were prepared. Three-dimensional culture was done for 5 days under a low osmotic condition $(270 \mathrm{mOsm})$ as seen osteoarthritis or a normal osmotic condition like that of healthy cartilage (370 mOsm). Transforming growth factor- $\beta$ (TGF- $\beta$ ) and fibroblast growth factor-2 (FGF-2) were added every day. GAG production was assessed by the dimethylmethylene blue (DMB) assay after 5 days. Fig. 8 shows the effect of osmorality and growth factor on the amount of GAG accumulated with time in culture. Significantly more GAG was accumulated by cells cultured at 370 Osm than low osmoralities $(270 \mathrm{mOsm})$. The cells cultured with the growth factors (TGF$\beta$ or FGF-2) were more active and accumulated significantly more GAG accumulated than cells cultured without the growth factors. However, GAG accumulated was significantly lower for cells cultured at $270 \mathrm{mOsm}$ than those at $370 \mathrm{mOsm}$. Thus, the clinical application of cartilage regeneration medicine needs to be advanced by providing appropriate physiological conditions with consideration of age-related cartilaginous changes.

The interrelationships between cell density, cell viability and activity, and diffusion distance resulting from nutrient supply constraints, limit the rate at which GAG can be accumulated in three-dimensional constructs. GAG accumulation depends on GAG production per cell and on cell density. GAG accumulation thus appears necessarily slow, and the general finding that cultures of $>7$ months are required to achieve concentrations of GAG similar to those seen in vivo may not be easily overcome (Kellner et al. 2002, Roughley, 2004). An increase in GAG 


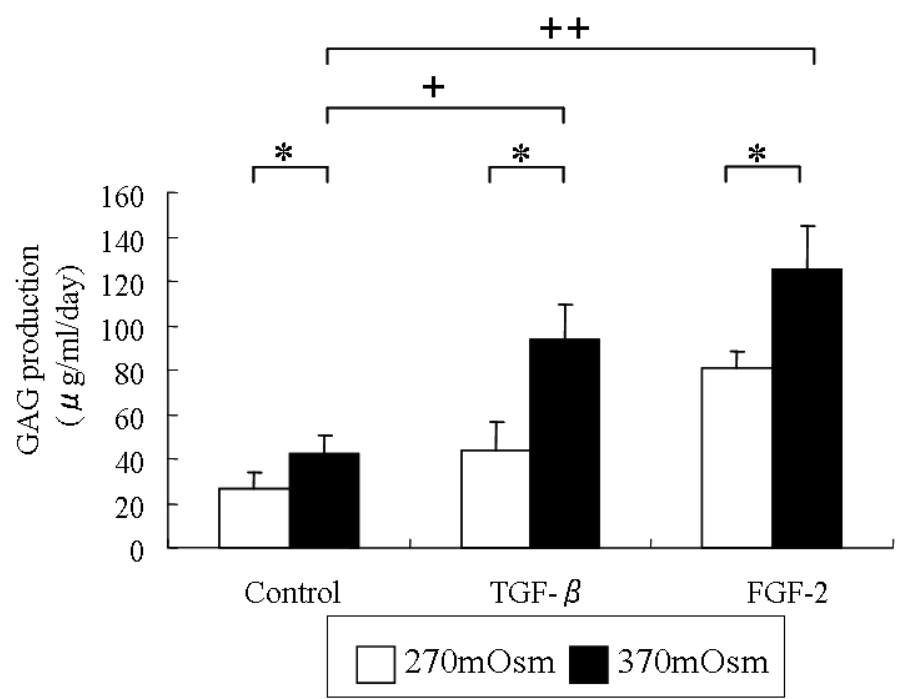

Figure 8. Effect of extracelluler osmotic change and growth factors on GAG accumulation/tissue volume. This figure gives pooled data for 2 representative osmolality from 6 separate experiments for cells cultured by articular chondrocytes. GAG production at $370 \mathrm{mOsm}$ was about $42.1 \pm 9.1 \mu \mathrm{g} / \mathrm{ml} /$ day, while it was only about $26.3 \pm 4.3 \mu \mathrm{g} / \mathrm{ml} / \mathrm{day}$ at 270 mOsm. During culture at 370 mOsm, GAG production was increased about 2-3 times by addition of growth factors, while there was a clear decrease in the response of GAG production to growth factors at 270 mOsm compared with that seen at 370 mOsm. Incubation with growth factors, enhances GAG production during culture at a normal osmotic pressure, but cell function is decreased in degenerated cartilage. Values are mean \pm standard error. (*: Scheffe between 270 mOsm and 370 mOsm medium, \#: $P<0.05$, Scheffe between control and every growth factors).

production rate per cell can be induced by addition of growth factors, but the relative increase which can be achieved is limited (usually two-threefold under optimal conditions) and the consequent increase in metabolic demand can lead to a fall in $\mathrm{pH}$ in the construct center and thus severely limit growth factor efficacy. In this study, addition of TGF- $\beta$, and FGF-2 to constructs was found to have big effect on the concentration of accumulated GAG under low osmoralities. Thus, increasing cell metabolism potentially should increase GAG deposition, but leads to a more nutrients demands.

\section{Effect of cell density on the rate of glycosaminoglycan accumulation by chondrocytes}

Glycosaminoglycan (GAG) accumulation in constructs is dependent on the rate of GAG production per cell and on the cell density. It seems intuitive, therefore, that increasing cell density should increase rate of GAG deposition, as indeed has been shown in several studies (Almarza \& Athanasiou, 2005, Mauck et al., 2002, Mauck et al., 2003b, Saini \& Wick, 2003, Williams et al., 2005, Kobayashi et al., 2008). However, it is apparent from these studies that 
GAG accumulation in the construct does not increase in proportion to cell density and, indeed, GAG production per cell appears to fall at high cell densities.

We used alginate gels in the form of beads as a model system (Fig.9). Cells were isolated from bovine metacarpal phalangeal joints. They were cultured in alginate beads in DMEM containing $6 \%$ FBS under $21 \% \mathrm{O}_{2}$ at cell densities from 1-33 million cells $/ \mathrm{ml}$. The amount of GAG accumulated in a typical culture of bovine articular chondrocytes increased with time in culture. After 7 days a bimodal response was evident with the concentration of GAG accumulated rising as cell density was increased from 1-10.4 million cells $/ \mathrm{ml}$ and then falling gradually as cell density was further increased (Fig.10A). However the GAG production per million cells fell as cell density was increased (Fig.10B).

Next, we mainly examined two initial seeding cell densities viz. 4 million cells/ml (Fig.9A) and 25 million cells/ml (Fig.9B); these represent cell densities often used in alginate beads and found in vivo in the cell density in adult cartilage from the bovine metacarpal-phalangeal joint.
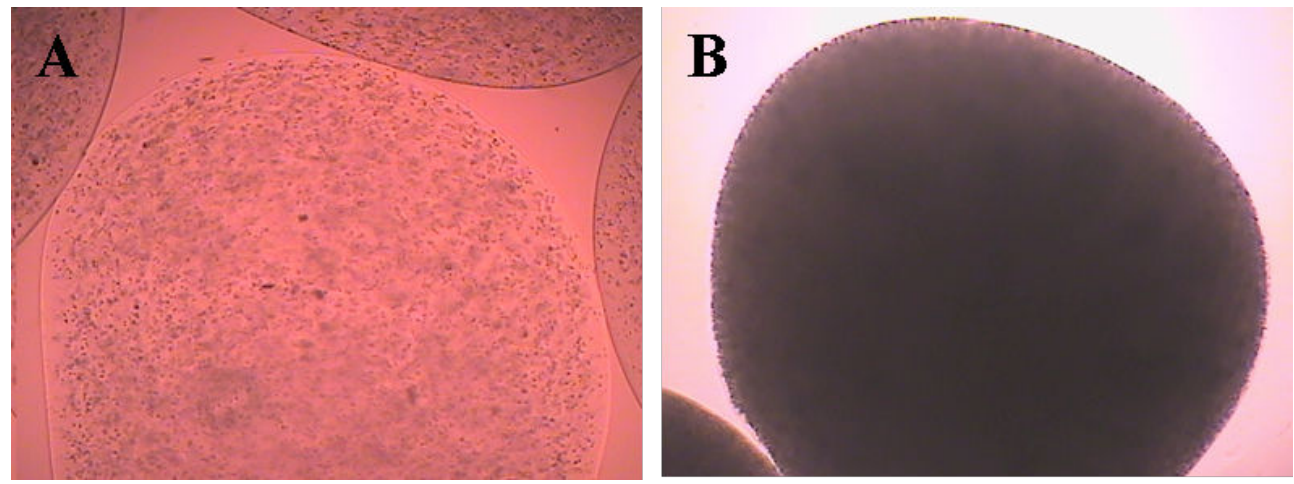

Figure 9. Three-dimensional cell culture system of alginate beads. (A) $4 \times 10^{6} \mathrm{cell} / \mathrm{ml}$, (B) $25 \times 10^{6} \mathrm{cell} / \mathrm{ml}$

Significantly more GAG was accumulated by cells cultured at high ( 25 million cells/ml) than low (4 million cells/ml) densities and in agreement with results shown in Fig.11, GAG accumulated also increased with time in culture. At 4 million cells $/ \mathrm{ml}$, the concentration of GAG in the bead reached $520.9 \pm 62.4 \mu \mathrm{g} / \mathrm{ml}$ in 5 days. These concentrations could be increased to $1297.2 \pm 115.2 \mu \mathrm{g} / \mathrm{ml}$ by raising cell density to 25 million cells $/ \mathrm{ml}$ (Fig.11A). The increase in amount of GAG accumulated was not directly proportional to increase in cell density; although the beads at high cell density contained more than 6 times as many cells as those at low cell density, they only produced only 2-3 times as much total GAG. After 5 days culture at 4 million cells/ml, GAG accumulation per cell was $166.3 \pm 38.9 \mu \mathrm{g}$ GAG/million cells (Fig.11B). These amounts fell to $70.9 \pm 23.9 \mu \mathrm{g} /$ million cells when cell density was increased to 25 million cells/ $\mathrm{ml}$. Thus, cells cultured at low density were more active and accumulated significantly more GAG per cell than cells cultured at high density. Evidence of greater cellular activity for cells cultured at low cell density was also seen from measurements of lactate production per live cell; lactate production was significantly higher for cells cultured at low density than for those 
A

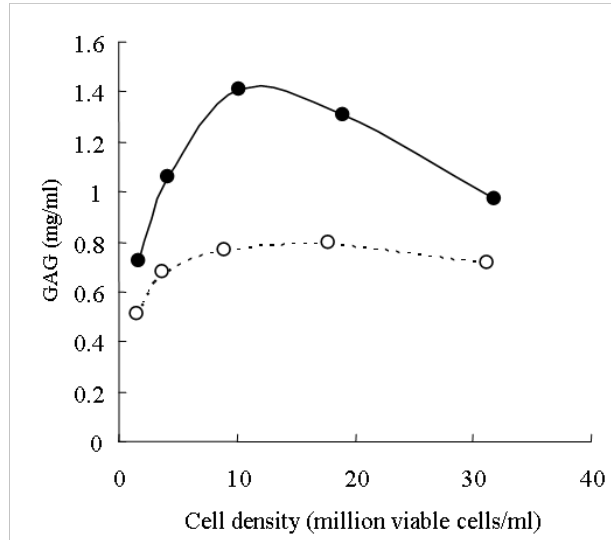

B

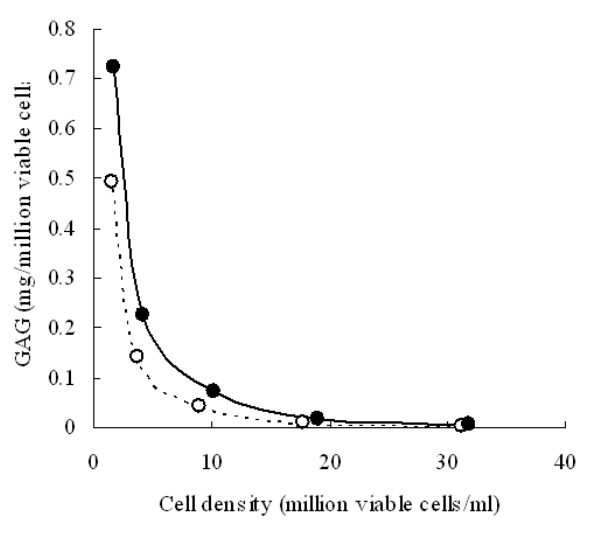

$$
\cdots \circ \cdots \text { day } 3 \longrightarrow \text { day } 7
$$

Figure 10. Typical results showing effect of cell density on GAG deposition (A) and on GAG accumulation per million cells (B) by articular chondrocytes. Cells were isolated, encapsulated in alginate beads at cell densities ranging from 1 to 33 million cells $/ \mathrm{ml}$. Beads were cultured for 7 days at 5 wells/bead in $2 \mathrm{ml}$ medium, 2 wells for each cell density and cultured for 7 days in DMEM containing $6 \%$ serum. Beads were then dissociated for cell counting and assay of total GAGs.

A

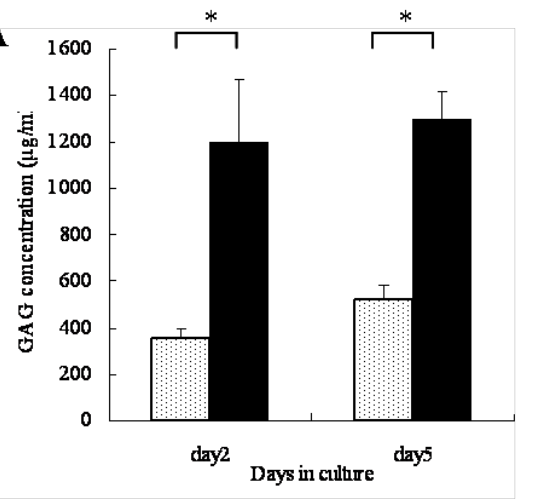

B

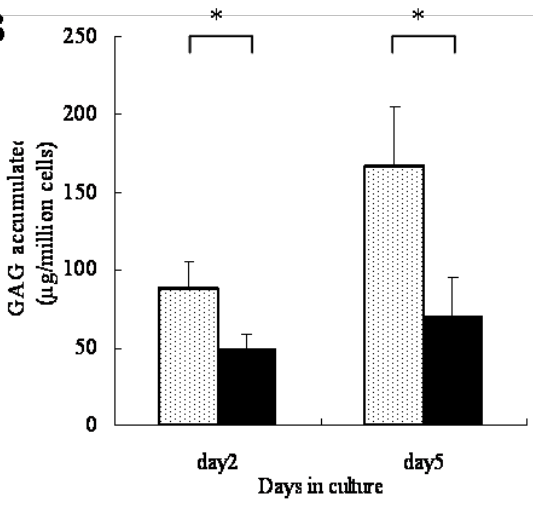

4 million cells $/ \mathrm{ml}$

25 million cells $/ \mathrm{ml}$

Figure 11. Effect of cell density on GAG concentration (A) and GAG accumulation per million cells (B) by articular chondrocytes after 2 days and 5 days in culture. Cells were encapsulated in alginate beads, cultured in DMEM with $6 \%$ serum under air and GAG concentration and cell density measured after 2 and 5 days culture. These figures give pooled data for the two representative cell densities from 3 separate experiments. Values are mean \pm standard error. ${ }^{*}$ : Significant difference $(P<0.05)$ between the high cell density $(25$ million cells $/ \mathrm{ml}$ ) and the low cell density $(4$ million cells/ml) using non-paired t test. 


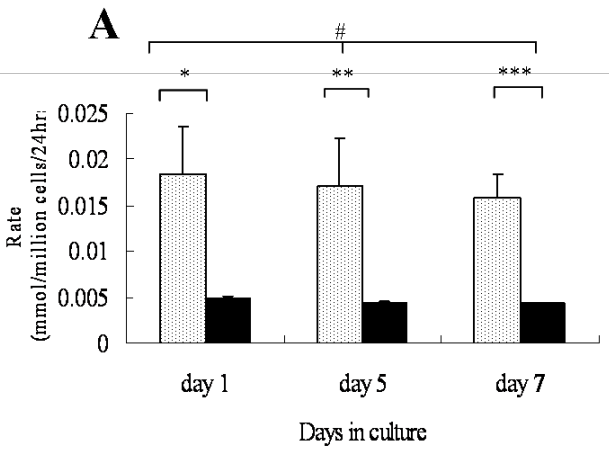

$\square$ million cells/ml

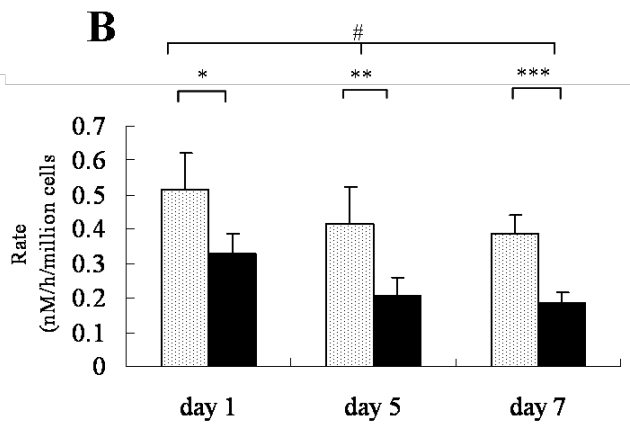

Days in culture

Figure 12. Effect of cell density on lactate production rate (A) and 35S-sulphate incorporation rate (B). (A) Cells were cultured under standard conditions in beads containing 4 and 25 million cells/ $\mathrm{ml}$ (1.0ml medium, 5 beads/well) for up to 7 days, with complete medium change daily. Representative beads were dissociated for cell counting and viable cell density/bead recorded. Lactate in the medium was measured at days 1,5 and 7, after 24 hours culture and rates per million cells $/ 24 \mathrm{hrs}$ reported. High cell density lead to a fall in cellular metabolism $(*, * *, * * *$ : P $<0.05$, Paired $t$ test between high [ 25 million cells $/ \mathrm{ml}$ ] and low cell density [4 million cells $/ \mathrm{ml}]$ ). Lactate production rate fall with time in culture (\#: $\mathrm{P}<0.05,2$ way ANOVA with repeated measures among 1, 5 and 7 days).(B) At days 1,5 and 7, tracer sulphate was added to the fresh medium of 3 wells, the beads were cultured in the radioactive solution for 4 hours, the beads dissociated and cell density and sulphate incorporation measured (Fig 3B). Results are given as means \pm s.e.m of 3 independent experiments. Sulphate incorporation rates fall with increase in cell density $\left(*,{ }^{*}, * * *\right.$ : $P<0.05, P$ aired $t$ test between high [ 25 million cells $/ \mathrm{ml}]$ and low cell density [ 4 million cells $/ \mathrm{ml}])$ and with time in culture $(\#: P<0.05,2$ way ANOVA with repeated measures among 1, 5 and 7 days).

cultured at high density (Fig 12A). Lactate production also decreased with time in culture, more rapidly at high than at low cell densities. The rate of sulphate incorporation per live cell was also greater at low than at high cell densities (Fig.12B), though the difference was less marked than that seen in Fig.12A; sulphate incorporation fell more steeply than lactate production with time in culture.

The change in percentage of live and dead cells with time in culture at the periphery and centre of beads is shown in Fig.13 for cells cultured at low (4 million cells $/ \mathrm{ml})$ and high cell densities (25 million cells $/ \mathrm{ml}$ ), respectively. For cells cultured at 4 million cells $/ \mathrm{ml}, 100 \%$ of the cells were viable at the both the periphery (Fig 13A) and in the centre (Fig 13B). It can be seen that by day 2 of culture at high cell densities, while almost all the cells at the periphery were alive (Fig. 13C,E), 30 percent of the cells in the bead centre were dead (Fig.13D,E). Similar percentages were dead at day 5 of culture, suggesting the profile of viable cells across the bead was established early in culture.

From sections of beads cultured for 5 days at 4 and 25 million cells $/ \mathrm{ml}$ and then stained with safranine $\mathrm{O}$ to visualise the sulphated GAGs accumulated (Fig.14A-D), there was a noticeable difference between staining at the bead periphery (Fig.14A,C) and the bead centre (Fig. 14B,D). From densitometric measurements, GAG accumulated at centre of beads cultured at 25 million cells per $\mathrm{ml}$ was only $60-70 \%$ of that accumulated at the periphery (Fig.14E). Less staining was seen in beads cultured at 4 million cells per $\mathrm{ml}$ as seen also from chemical 

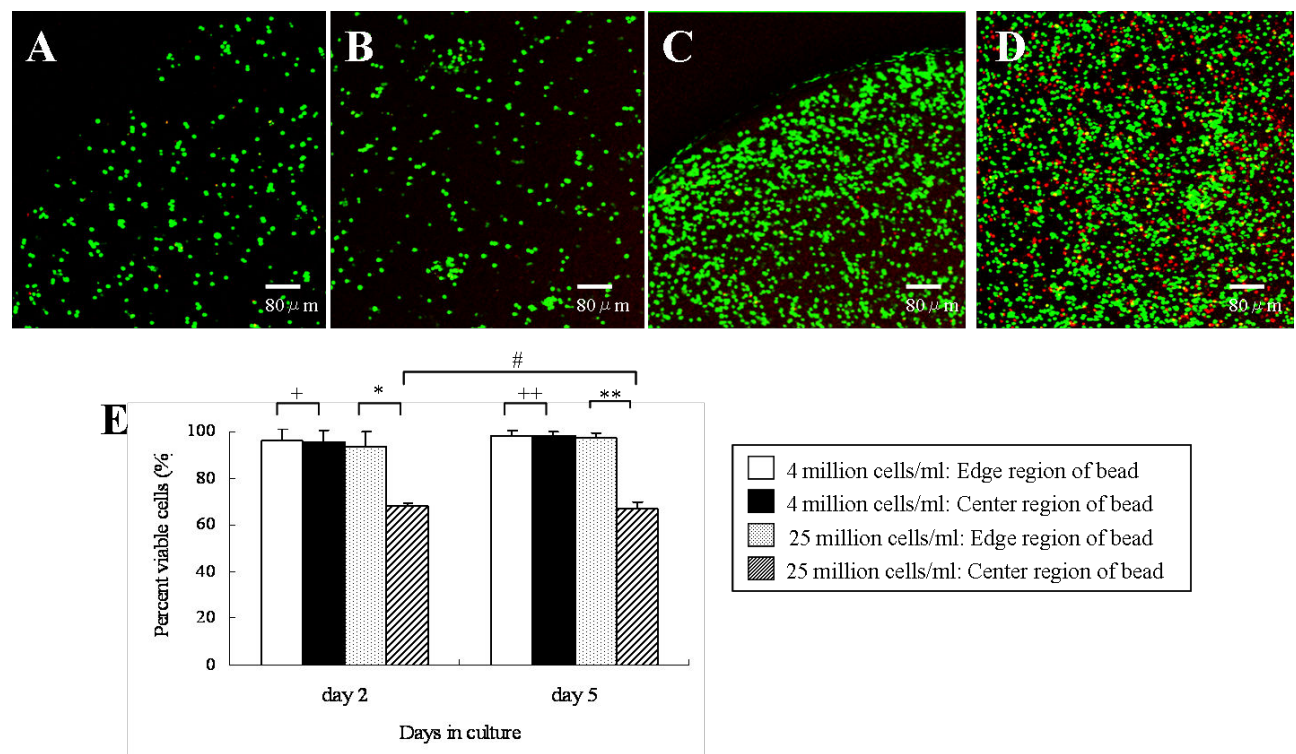

Figure 13. Effect of cell density on cell viability under conforcal microscope. This shows the variation of cell viability at the edge and centre of beads with time and cell density. Cell viability was determined using a live/dead assay kit; live cells (green) and dead cells (red) were counted manually. Results are means and s.e.ms of percentage of viable cell from 4 representative beads. Figs $13 \mathrm{~A}$ and $13 \mathrm{~B}$ shows the periphery and central region respectively of a typical bead cultured at 4 million cells $/ \mathrm{ml}$ after 5 days. Figs 13C and 13D shows the periphery and central region of a bead cultured at 25 million cells $/ \mathrm{ml}$ after 5 days. Fig 13 E shows the variation of cell viability with region (edge versus centre). At high cell density ( 25 million cells $/ \mathrm{ml})$, cell viability is lower in the centre than at the edge $\left(+: \mathrm{P}=0.977,++: \mathrm{P}=0.893,{ }^{*},{ }^{* *}\right.$ : $\mathrm{P}<0.05,2$ way ANOVA with repeated measures between edge and centre).

analysis. At this low density however there was no significant profile of GAG accumulation across the bead, with the amount accumulated in the centre similar to that accumulated at the periphery.

At low cell density, transmission electron micrographs indicated that all cells appeared viable and active (Fig.15A). Chondrocytes cultured at high cell density appeared viable at the bead periphery (Fig.15B). However cells undergoing apoptosis were seen in the centre; the cells and nuclei were reduced in size and chromatin condensation was visible in the nuclei (Fig. 15C,D). These results are in agreement with those of others who have found regions of cell death in the center of constructs or even of microsphere aggregates (Martin et al., 1999b, Mercier et al., 2004, Obradovic et al., 1999), and that glycosaminoglycan accumulation may highest at the construct peripheries. In addition, others have also found that increasing cell density or cell number does not necessarily increase matrix accumulation (Mercier et al., 2004).

These avascular constructs, unless experimentally perfused, rely on diffusion for supply of nutrients to the cells (Obradovic et al., 2000) simulating the condition seen in cartilaginous tissue. In avascular tissues and in constructs, there are steep gradients of oxygen and other nutrients between the surface and center of the tissue or constructs (Kellner et al., 2002, Malda 

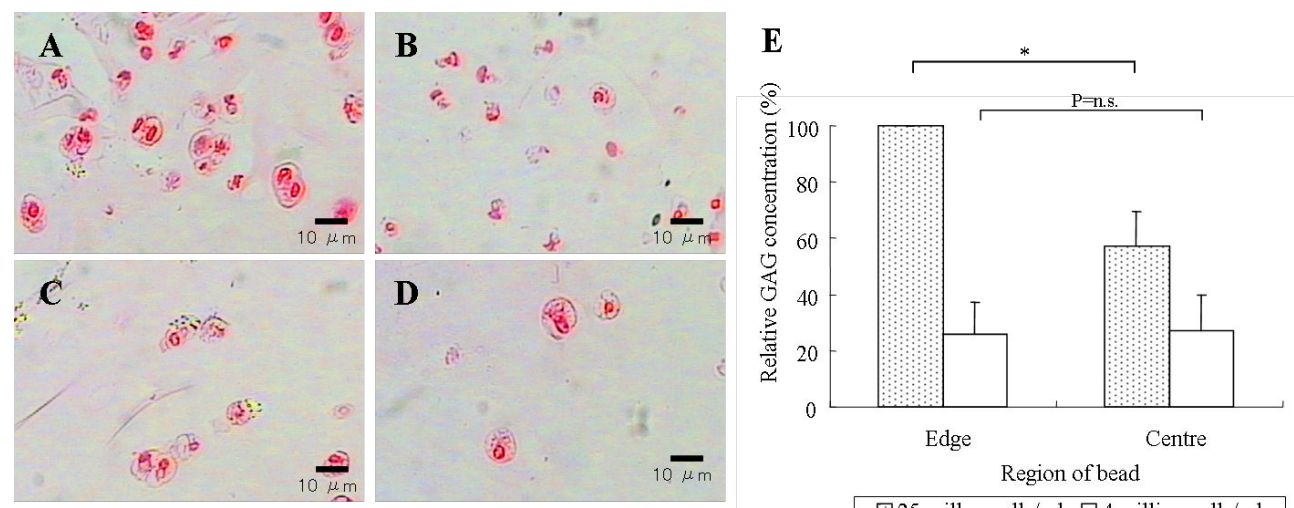

. 25 millon cells/ml $\square 4$ million cells/ml

Figure 14. Effect of cell density on GAG deposition by Safranine O staining after 5 days culture.Fig 4A shows a 20micron section through a typical bead of chondrocytes cultured at 25 million cells/ml $(A, B)$ and at 4 million cells/ml $(C, D)$ cultured for 5 days. Images at the periphery $(A, C)$ and at the centre $(B, D)$ were captured digitally and the GAG around cells was quantified using image-analysis. Results are reported as the fraction of stained area in the peripheral and central regions of the beads and data normalized to results at 25 million cells/ml (E). At high cell density, the area of the staining was higher at the edge of the bead ( $*$ : $<<0.05$, Paired $t$ test between edge and centre). At low cell density, however, there was no significant profile of GAG accumulation between edge and centre $(P=0.712$, Paired t test between edge and centre).

et al., 2004). The steepness of these gradients, and hence the nutrient concentrations in the center of the construct, depend not only on the geometry and properties of the tissue or construct but also on the cell density and the cellular activity (Haselgrove et al., 1993, Zhou et al., 2004, Soukane et al., 2005). Thus, in any particular construct or tissue, an increase in cell density will lead to a corresponding fall in the concentration of nutrients such as oxygen and glucose, and an increase of metabolic by-products such as lactic acid (Zhou et al., 2004), leading, once cell density has risen sufficiently, to a fall in rates of cell metabolism and glycosaminoglycan synthesis (Gray et al., 1988, Ysart \& Mason, 1994). If cell density is sufficiently great, oxygen and glucose concentrations and $\mathrm{pH}$ levels can fall to levels which can no longer sustain viable cells (Horner \& Urban, 2001) leading to the necrotic region in the construct center. Diffusional nutrient transport is thus a limitation on the number of viable and active cells which can be maintained in any construct or tissue; indeed, viable cell density is inversely related to diffusion distance both in disc and in constructs (Horner \& Urban, 2001, Stockwell, 1971).

\section{Physical limitations to biological repair and tissue engineering}

The interrelationships between cell density, cell viability and activity, and diffusion distance resulting from nutrient supply constraints, limit the rate at which GAG can be accumulated in three-dimensional constructs. GAG accumulation depends on GAG production per cell and on cell density. At low cell densities, cells may be functioning optimally but the low cell density 

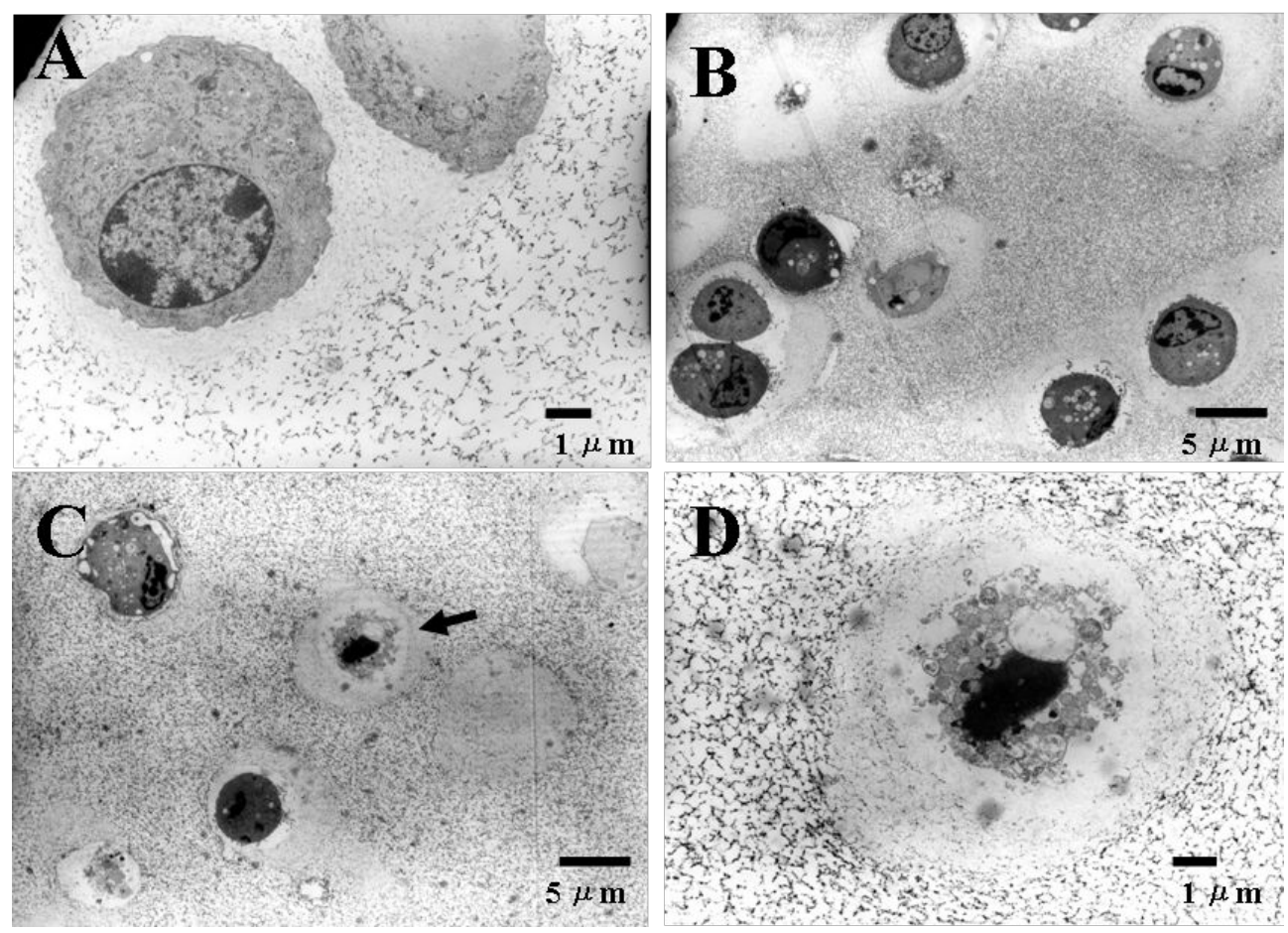

Figure 15. Electron micrographs of central and peripheral articular chondrocytes cultured at low (A) and high cell density (B-D). These pictures show representative cells from the central and peripheral regions of beads cultured at low (4 million cells/ml) and high ( 25 million cells/ml) for 5 days. (A) Central region, low cell density, cells appear normal. (B-D) High cell density (25 million cells/ml). (B) Bead periphery, some cells appear normal. (C) Central region showing cells undergoing apoptosis (arrow). The cells and nuclei were reduced in size and chromatin condensation was seen in the nuclei in comparison of the cells in the periphery. (D) High power magnification of apototic nucleus pulposus cell.

limits the rate of GAG accumulation. At high cell densities, more GAG is deposited at least initially, but nutrient gradients particularly in the center of constructs, reduce the rate of GAG deposition per cell and may even lead to a fall in cell number if cells die. GAG accumulation thus appears necessarily slow, and the general finding that cultures of $>7$ months are required to achieve concentrations of GAG similar to those seen in vivo may not be easily overcome (Kellner et al., 2002, Roughley, 2004). The different maneuvers which have been tried to increase GAG production all have limitations. An increase in GAG production rate per cell can be induced by addition of growth factors, by providing mechanical or ultrasound stimulation or through alterations to scaffold properties (Blunk et al., 2002, Richmon et al., 2005, van der Kraan et al., 2002, Kuo \& Lin, 2006), but the relative increase which can be achieved is limited (usually two-three fold under optimal conditions) and the consequent increase in metabolic demand can lead to a fall in $\mathrm{pH}$ in the construct center (Wu, M.H. et al., 2008) and thus severely limit growth factor efficacy. Indeed, addition of anabolic growth factors, such as 
Transforming growth factor- $\beta$ (TGF- $\beta$ ) (Morales, et al. 1988, 1991a,b, Luyten, et al. 1988, van Osch, et al. 1998, Diao, H. et al. 2009,), bone morphogenetic protein-2 (BMP-2) (van Beuningen, et al. 1998, Blaney Davidson, et al. 2007), bone morphogenetic protein-7 (BMP-7) (Chubinskaya, et al. 2007, Hayashi, et al. 2008), insulin growth factors-1 (IGF-1) (Luyten, et al. 1988, van Osch, et al. 1998, Fortier, et al. 2002, Goodrich, et al. 2007) and fibroblastic growth factor (FGF) (Martin, et al. 1999a, Maehara, et al. 2010), to constructs was found to have little effect on the concentration of accumulated GAG although it increased construct size. In addition, GAG production rates appear to fall with time in culture in many different systems also limiting GAG accumulation (Mercier et al., 2004). Increasing cell density potentially should increase GAG deposition, but leads to a lower activity per cell, and also, in general, has not been found to increase GAG deposition rates (Panossian et al., 2001). It should also be noted that tissue in vivo cannot support too high a cell density, so in vitro culture of constructs at high cell density could lead to cell death after implantation.

Culture conditions such as stirring or perfusion (Freyria et al., 2000, Seidel et al., 2004) appear able to overcome diffusive transport initially, but as GAG concentrations rise and the hydraulic permeability of the construct falls, convective transport also is reduced and rates of GAG deposition slow. GAG concentrations were reported to reach $5 \%$ by wet weight within 2 months but took a further 5 months to increase to 7\% GAG. In view of the long culture times which appear necessary to achieve the required GAG composition in vitro, achievement of in vivo concentration before implantation of a construct may be an unrealistic and possibly unnecessary goal for tissue engineered disc. It has been suggested that about 2-3 fold amount of GAG can be produced using anabolic growth factors. Even if such growth factors are used, more than 100 days of culture is thought to be necessary. Furthermore, it has been reported that turnover of GAG in the cartilage tissue takes about 2 - 3 years (Maroudas, 1975). So, GAG is slowly synthesized in the biological condition, and a long time is necessary to construct articular cartilage with adequate mechanical strength even if cells are maintained in active status by three-dimensional culture. Anabolic growth factors were obvious tools to enhance cartilage repair. Recently, Carragee et al (2011). reported that the bone morphogenic protein-2 (BMP-2) has cancer risk associated with the use of BMP-2 in spinal fusion surgery. In the future, orthopaedic surgeons must exercise caution to use the anabolic growth factors in clinics.

At present, the target diseases of treatment utilizing bioengineering (tissue engineering) such as chondrocytes implantation are local lesions such as traumatic cartilage defect and osteochondritis dissecans (Bittberg, 1999, Minas, 2001, Ochi, et al. 2002, Robert, et al. 2003) (Fig. 16A). For regeneration of extensive degenerated cartilage in OA, it is necessary to secure a large amount of chondrocytes for implantation. If a large graft is implanted, a nutritional problem may occur as explained above. In addition, the subchondral bone needs to be healthy to obtain the normal function of articular cartilage such as dispersion of load. But, lesion of $\mathrm{OA}$ is not localized in the cartilage layer but involves the subchondral bone (e.g., osteosclerosis) (Fig.16B). The osteosclerosis which is the subchondral bone, covers the bone-cartilage junction with age and looks to close the nutritional route through these vascular system (Trueta, 1963, Havelka, et al. 1984). Therefore, even if regeneration of cartilage is achieved by means of hyaline cartilage, the regenerated cartilage may sustain overload and may be degenerated 
A. Acute osteochondral disease

- Cartilage injuty/defect

- Osteochondritis dissecans

Extracellular enviroment

$1-5 \% \mathrm{O}_{2}$,

$\mathrm{pH} 7.2-7.4$

$370 \mathrm{mOsm}$

Subchondral bone

Blood vessels

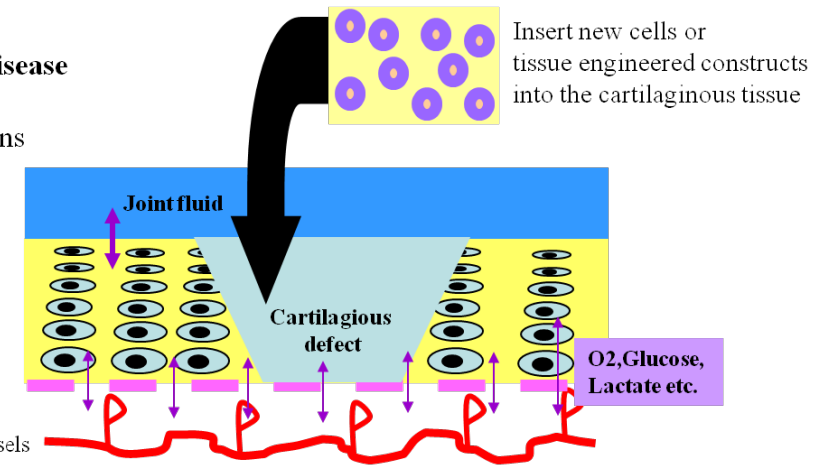

B. Chronic Osteochondral disease

- Osteoarthritis $(\mathrm{OA})$

- Rheumatoid arthritis (RA)
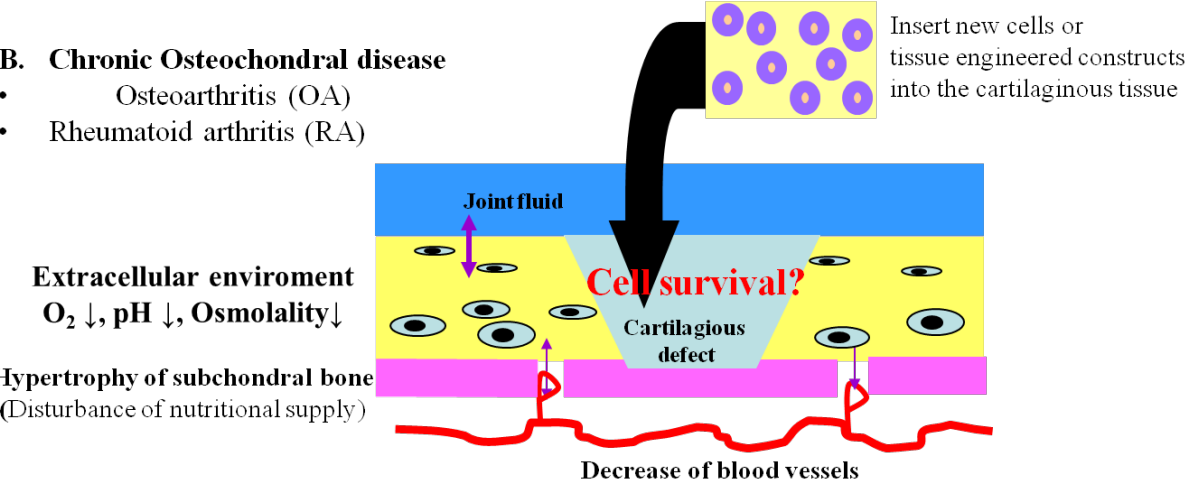

Figure 16. Target diseases of treatment utilizing bioengineering or tissue engineering technique.(A) Chondrocytes implantation is local lesions such as traumatic cartilage defect and osteochondritis dissecans at present. However, GAG is slowly synthesized in the biological condition, and a long time is necessary to construct articular cartilage with adequate mechanical strength even if cells are maintained in active status by culture.(B) Biological repair depends on the cartilaginous tissue maintaining a population of viable and active cells. If, in some degenerate cartilaginous tissues, nutrient supply is impeded (as it seems to be) hence resident cells are inactive or die. Therefore, we have to consider chemical and ionic environments in the degenerative cartilage before performing the tissue engineering of cartilaginous tissue.

again unless the mechanical environment is modified together. Cellular repair using autologous chondrocyte transplantation appears successful even though chondrocytes are implanted with no matrix at all. Under these conditions, remodeling in vivo appears to produce a cartilage-type matrix under some conditions. Tissue engineered composites implanted with low GAG appeared to accumulate GAG in vivo, withstand physiological loading, and remodel towards a hyaline-type matrix. Perhaps optimization of such processes is a more useful goal.

\section{Conclusions}

There is increasing interest in the using biological methods to repair osteoarthritis. Biological repair depends on the articular cartilage maintaining a population of viable and active cells. 
Adequate nutrition of the cartilaginous tissue influences the outcome of such therapies and, hence, must be considered to be a crucial parameter. Therefore, it is very important to maintain an appropriate physicochemical environment to achieve successful cartilage repair by biological methods and tissue engineering procedures.

\section{Acknowledgements}

I would like to thank Mr. Kohei Negoro, Mr. Tsuyoshi Miyazaki and Mr. Kenichi Takeno of the Orthopaedic Surgery, Fukui University for their technical assistance . I am grateful for the editorial assistance and comments of Dr. Jill Urban and Mr. Adam Meir of the Physiology Laboratory, Oxford University, UK.

\section{Author details}

Shigeru Kobayashi ${ }^{1,2}$

Address all correspondence to: kshigeru@u-fukui.ac.jp

1 Department of Orthopaedics and Rehabilitation Medicine, Faculty of Medical Sciences, The University of Fukui, Fukui, Japan

2 Research and Education Program for Life Science. The University of Fukui, Fukui, Japan

\section{References}

[1] Almarza, A. J, \& Athanasiou, K. A. (2005). Effects of initial cell seeding density for the tissue engineering of the temporomandibular joint disc. Ann Biomed Eng, 33, 943-950.

[2] Blaney Davidson E.N., Vitters, E.L., van Lent, P.L., et al. (2007). Elevated extracellular matrix production and degradation upon bone morphogenetic protein-2 (BMP-2) stimulation point toward a role for BMP-2 in cartilage repair and remodeling. Arthritis Res Ther, 9: R102.

[3] Blunk, T, Sieminski, A. L, Gooch, K. J, et al. (2002). Differential effects of growth actors on tissue-engineered cartilage. Tissue Eng, 8, 73-84.

[4] Botter, S. M, Van Osch, G. J, Clockaerts, S, et al. (2011). Osteoarthritis induction leads to early and temporal subchondral plate porosity in the tibial plateau of mice: An in vivo micro CT study. Arthritis Rheum, , 63, 2690-2699. 
[5] Brittberg, M, Lindahl, A, Nilsson, A, et al. (1994). Treatment of deep cartilage defects in the knee with autologous chondrocyte transplantation. N Engl J Med, 331, 889-895.

[6] Brittberg, M. (1999). Autologous chondrocyte transplantation. Clin Orthop Relat Res, 367: S, 147-155.

[7] Brower, T. D, Akahishi, Y, \& Orlic, P. (1962). The diffusion of dyes through articular cartilage in vitro. J Bone and Joint Surg, A: 456-463., 44.

[8] Burgess, W. H, \& Maciag, T. (1989). The heparin-binding (fibroblast) growth factor family of proteins. Annu Rev Biochem 58, 575-606.

[9] Burton-wurster, N, \& Lust, G. (1990). Fibronectin and proteoglycan synthesis in long term cultures of cartilage explants in Ham's F12 supplemented with insulin and calcium: effects of the addition of TGF-beta. Arch Biochem Biophys, 283, 27-33.

[10] Bush, P. G, \& Hall, A. C. (2001). The osmotic sensitivity of isolated and in situ bovine articular chondrocytes. J Orthop Res, , 19, 768-778.

[11] Bush, P. G, Hodkinson, P. D, Halmilton, G. L, et al. (2005). Viability and volume of in situ bovine articular chondrocytes, changes following a single impact and effects of medium osmolarity. Osteoarthritis Cartilage, 13, 54-65.

[12] Carragee, E. J, Eric, L, Hurwitz, D. C, \& Weiner, B. K. (2011). A critical review of recombinant human bone morphogenetic protein-2 trials in spinal surgery: emerging safety concerns and lessons learned. Spine J, 11, 471-491.

[13] Chubinskaya, S, Hurtig, M, \& Rueger, D. C. in cartilage repair. Int Orthop, , 31, 773-781.

[14] Diao, H, Wang, J, Shen, C, et al. (2009). Improved cartilage regeneration utilizing mesenchymal stem cells in TGF-beta 1 gene-activated scaffolds. Tissue Eng Part A, , $15,2687-2698$.

[15] Duncan, H, Jundt, J. W, Riddle, J. M, et al. (1987). The tibial subchondral plate. J Bone Joint Surg 69, 1212-1220.

[16] Edwards, D. R, Murphy, G, Reynolds, J. J, et al. (1987). Transforming growth factor beta modulates the expression of collagenase and metalloproteinase inhibitor. EMBO J, 6, 1899-1904.

[17] Erickson, G. R, Alexopoulos, L. G, \& Guilak, F. (2001). Hyper-osmotic stress induces volume change and calcium transients in chondrocytes by transmembrane, phospholipid, and G-protein pathways. J Biomech, 34, 1527-1535.

[18] Fortier, L. A, Mohammed, H. O, Lust, G, et al. (2002). Insulin-like growth factor-I enhances cell-based repair of articular cartilage. J Bone Joint Surg, B :276-288., 84. 
[19] Goodrich, L. R, Hidaka, C, Robbins, P. D, et al. (2007). Genetic modification of chondrocytes with insulin-like growth factor-1 enhances cartilage healing in an equine model. J Bone Joint Surg, B:672-685., 89.

[20] Gospodarowicz, D, Ferrara, N, Schweigerer, L, et al. (1987). Structural characterization and biological functions of fibroblast growth factor. Endocr Rev, 8, 95-114.

[21] Gray, M. L, Pizzanelli, A. M, Grodzinsky, A. J, et al. (1988). Mechanical and physiochemical determinants of the chondrocyte biosynthetic response. J Orthop Res, 6, 777-792.

[22] Gray, M. L, Pizzanelli, A. M, Lee, R. C, et al. (1989). Kinetic of the chondrocyte biosynthetic response to compressive loading and release. Biochem Biophys Acta, 991, 415-425.

[23] Hall, A.C., Pickles, D.M., MacDonald, A.G. (1993). Aspects of eukaryotic cells. Adv Comp Environ Physiol, 17, 29-85.

[24] Haselgrove, J. C, Shapiro, I. M, \& Silverton, S. F. (1993). Computer modeling of the oxygen supply and demand of cells of the avian growth cartilage. Am J Physiol, 265, CC506., 497.

[25] Havelka, S, Avelka, S, Horn, V, et al. (1984). The calcified-non calcified cartilage interface; the tidemark. Acta Biol Hung, , 35, 271-279.

[26] Hayashi, M, Muneta, T, Ju, Y. J, et al. (2008). Weekly intra-articular injections of bone morphogenetic protein-7 inhibits osteoarthritis progression. Arthritis Res Ther, 10: R118.

[27] Hodge, J. A, \& Mckibbin, B. (1969). The nutrition of mature and immature cartilage in rabbits. An autoradiographic study. J Bone and Joint Surg, B: 140-147., 51.

[28] Hodge, W. A, Fijan, R. S, Carlson, K. L, et al. (1986). Contact pressures in the human hip joint measured in vivo. Proc Natl Acad Sci USA, 83, 2879-2883.

[29] Hopewell, B, \& Urban, J. P. G. (2003). Adaptation of articular chondrocytes to changes in osmolality. Biorheology, 40, 73-77.

[30] Horner, H. A, \& Urban, J. P. (2001). Volvo Award Winner in Basic Science Studies: Effect of nutrient supply on the viability of cells from the nucleus pulposus of the intervertebral disc. Spine, 26, 2543-2549.

[31] Huck, K. (2001). Long-term effects of osteogenic protein-1 on biosynthesis and proliferation of human articular chondrocytes. Clin Exp Rheumatol 19, 525-531.

[32] Kellner, K, Liebsch, G, Klimant, I, et al. (2002). Determination of oxygen gradients in engineered $\mathrm{t}$ issue using a fluorescent sensor. Biotechnol Bioeng, 80, 73-83. 
[33] Kempson, D. E, Muir, H, Swanson, S. A, \& Freemann, M. A. (1970). Correlations between stiffness and the chemical constituents of cartilage on the human femoral head. Biochem Biophys Acta 215, 70-77.

[34] Kobayashi, S, Meir, A, \& Urban, J. P. G. (2008). The effect of cell density on the rate of glycosaminoglycan accumulation by disc and cartilage cells in vitro. J Orthop Res, 26, 493-503.

[35] Kühn, K, Lima, D, Hashimoto, D. D, et al. (2004). Cell death in cartilage. Osteoarthritis Cartilage 12, 1-15.

[36] Kuo, Y. C, \& Lin, C. Y. (2006). Effect of genipin-crosslinked chitin-chitosan scaffolds with hydroxyapatite modifications on the cultivation of bovine knee chondrocytes. Biotechnol Bioeng, 95, 132-144.

[37] Lane, L. B, Villacin, A, \& Bullough, P. G. (1977). The vascularity and remodelling of subchondral bone and calcified cartilage in adult human femoral and humeral heads. J Bone Joint Surg, B: 272-278., 59.

[38] Lane, L. B, \& Villacin, A. (1980). Age-related changes in the thickness of the calcified zone and the number of tidemarks in adult human articular cartilage. J Bone Joint Surg, B: 372-375., 62.

[39] Lane, J. M, Brighton, C. T, \& Menkowitz, B. J. (1977). Anaerobic and aerobic metabolism in articular cartilage. J Rheumatol, 4, 334-342.

[40] Lee, R. B, \& Urban, J. P. G. (1997). Evidence for a negative Pasteur effect in articular cartilage. Biochem $J_{1}$, 321, 95-102.

[41] Lee, R. B, \& Urban, J. P. G. (2002). Functional replacement of oxygen by other oxidants in articular cartilage. Arthritis Rheum, , 46, 3190-3200.

[42] Luyten, F. P, Hascall, V. C, \& Nissley, S. P. (1988). Insulin-like growth factors maintain steady-state metabolism of proteoglycans in bovine articular cartilage explants. Arch Biochem Biophys, 267, 416-425.

[43] Maehara, H, Sotome, S, Yoshii, T, et al. (2010). Repair of large osteochondral defects in rabbits using porous hydroxyapatite/collagen (HAp/Col) and fibroblast growth factor-2 (FGF-2). J Orthop Res, , 28, 677-686.

[44] Malda, J, Rouwkema, J, Martens, D. E, et al. (2004). Oxygen gradients in tissue-engineered PEGT/PBT cartilaginous constructs: measurement and modeling. Biotechnol Bioeng, , 86, 9-18.

[45] Manjo, G, \& Joris, I. (1995). Apotosis, oncosis, and necrosis. An overview of cell death. Am J Pathol „146, 3-19.

[46] Mankin, H . J. (1963). Localization of tritiated cytidine in articular cartilage of immature and adult rabbits after intraarticular injection. Lab Invest, 12, 543-548. 
[47] Maroudas, A, Bullough, P, Swanson, S. A. V, \& Freeman, M. A. R. (1968). The permeability of articular cartilage. J Bone and Joint Surg B: 166-177., 50.

[48] Maroudas, A. (1975). Glycosaminoglycan turn-over in articular cartilage. Philos Trans R Soc Lond B Biol Sci , , 271, 293-313.

[49] Maroudas, A. (1979). Physico-chemical propertiesof articular cartilage. In Marf (Ed.) Adult Articular Cartilage. Tunbridge Wells, England: Pitman Medical, , 215-290.

[50] Maroudas, A, \& Bannon, C. (1981). Measurement of swelling pressure in cartilage and comparison with the osmotic pressure of constituent proteoglycans. Biorheology ", $18,619-633$.

[51] Martin, I, Padera, R. F, Vunjak-novakovic, G, et al. (1998). In vitro differentiation of chick embryo bone marrow stromal cells into cartilaginous and bone-like tissues. J Orthop Res, 16, 181-189.

[52] Martin, I, Vunjak-novakovic, G, Yang, J, et al. (1999a). Mammalian chondrocytes expanded in the presence of fibroblast growth factor 2 maintain the ability to differentiate and regenerate three-dimensional cartilaginous tissue. Exp Cell Res, 253, 681-688.

[53] Martin, I, Obradovic, B, Freed, L. E, et al. (1999b). Method for quantitative analysis of glycosaminoglycan distribution in cultured natural and engineered cartilage. Ann Biomed Eng, 27, 656-662.

[54] Martin, I, Suetterlin, R, Baschongm, W, et al. (2001). Enhanced cartilage tissue engineering by sequential exposure of chondrocytes to FGF-2 during 2D expansion and BMP-2 during 3D cultivation. J Cell Biochem, 83, 121-128.

[55] Mauck, R. L, Seyhan, S. L, Ateshian, G. A, et al. (2002). Influence of seeding density and dynamic deformational loading on the developing structure/function relationships of chondrocyte-seeded agarose hydrogels. Ann of Biomed Eng, 30, 1046-1056.

[56] Mauck, R. L, Hung, C. T, \& Ateshian, G. A. (2003a). Modeling of neutral solute transport in a dynamically loaded porous permeable gel: Implications for articular cartilage biosynthesis and tissue engineering. J Biomech Eng ", 125, 602-614.

[57] Mauck, R. L, Wang, C. C, Oswald, E. S, et al. (2003b). The role of cell seeding density and nutrient supply for articular cartilage tissue engineering with deformational loading. Osteoarthritis Cartilage, 11, 879-890.

[58] Mcdevitt, C. A, \& Muir, H. (1976). Biochemical changes in the cartilage of the knee in experimental and natural osteoarthritis in the dog. J Bone Joint Surg, B: 94-101., 58.

[59] Mckibbin, B, \& Holdsworth, F. W. (1966). The nutrition of immature joint cartilage in the Lamb. J Bone and Joint Surg, B: 793-803., 48.

[60] Mercier, N. R, Costantino, H. R, Tracy, M. A, et al. (2004). A novel injectable approach for cartilage formation in vivo using PLG microspheres. Ann Biomed Eng, 32, 418-429. 
[61] Milz, S, \& Putz, R. (1994). Quantitative morphology of the subchondral plate of the tibial plateau. J Anat, 185, 103-110.

[62] Minas, T. (2001). Autologous chondrocyte implantation for focal chondral defects of the knee. Clin Othop 391S: S, 349-361.

[63] Morales, T. I, \& Roberts, A. B. (1988). Transforming growth factor beta regulates the metabolism of proteoglycans in bovine cartilage organ cultures. J Biol Chem, , 263, 12828-12831.

[64] Morales, T. I, Joyce, M. E, Sobel, M. E, et al. (1991a). Transforming growth factor-beta in calf articular cartilage organ cultures: synthesis and distribution. Arch Biochem Biophys ,, 288, 397-405.

[65] Morales, T. I. (1991b). Transforming growth factor-beta 1 stimulates synthesis of proteoglycan aggregates in calf articular cartilage organ cultures. Arch Biochem Biophys , 286, 99-106.

[66] Morales, T. I. (1994). Transforming growth factor- $\beta$ and Insulin-like growth factor-1 restore proteoglycan metabolism of bovine articular cartilage after depletion by retiboic acid. Arch Biochem Biophys, 315, 190-198.

[67] Negoro, K, Kobayashi, S, Taneno, K, et al. (2008). Effect of osmolarity on glycosaminoglycan production and cell metabolism of articular chondrocyte under three dimensional culture system. Clin Exp Rheumatol , 26, 527-533.

[68] Obradovic, B, Carrier, R. L, Vunjak-novakovic, G, et al. (1999). Gas exchange is essential for bioreactor cultivation of tissue engineered cartilage. Biotechnol Bioeng, 63, 197-205.

[69] Obradovic, B, Meldon, J. H, Freed, L. E, et al. (2000). Glycosaminoglycan deposition in engineered cartilage: Experiments and mathematical model. Aiche Journal, 46, 1860-1871.

[70] Ochi, M, Uchio, Y, Kawasaki, K, et al. (2002). Transplantation of cartilage-like tissue made by tissue engineering in the treatment of cartilage defects of the knee. $J$ Bone Joint Surg, B: 571-578., 84.

[71] Ogata, K, Whiteside, A, \& Lesker, P. A. (1978). Subchondral route for nutrition to articular cartilage in the rabbit. Measurement of diffusion with hydrogen gas in vivo. $J$ Bone and Joint Surg, A: 905-910., 60.

[72] O'Hara, B.P., Urban, J.P.G., \& Maroudas, A. (1990). Influence of cyclic loading on the nutrition of articular cartilage. Ann Rheum Dis, , 49, 536-539.

[73] Palmer, G. P, Chao, P. G, Raia, F, et al. (2001). Time-depandent aggrecan gene expression of articular chondrocytes in response to hyperosmotic loading. Osteoarthritis Cartilage 9, 761-770. 
[74] Pedrozo, H. A, Schwartz, Z, Gomez, R, et al. (1998). Growth plate chondrocytes store latent transforming growth factor (TGF)-beta 1 in their matrix through latent TGF-beta 1 binding protein-1. J Cell Physiol, 177, 343-354.

[75] Powers, C. J, Mcleskey, S. W, \& Wellstein, A. (2000). Fibroblast growth factors, their receptors and signaling. Endocr Relat Cancer , 7, 165-197.

[76] Risbud, M. V, \& Sittinger, M. (2002). Tissue engineering: advances in in vitro cartilage generation. Trends Biotechnol, , 20, 351-356.

[77] Redini, F, Min, W, Demoor, F. M, et al. (1997). Differential expression of membraneanchored proteoglycans in rabbit articular chondrocytes cultured in monolayers and in alginate beads. Effect of transforming growth factor-beta 1. Biochim Biophys Acta, , 1355, 20-32.

[78] Richmon, J. D, Sage, A. B, Shelton, E, et al. (2005). Effect of growth factors on cell proliferation, matrix deposition, and morphology of human nasal septal chondrocytes cultured in monolayer. Laryngoscope, 115, 1553-1560.

[79] Robert, S, Mccall, I. W, Darby, A. J, et al. (2003). Autologous chondrocyte implantation for cartilage repair: monitoring its success by magnetic resonance imaging and histology. Arthritis Res Ther , 5: RR73., 60.

[80] Roughley, P. J. (2004). Biology of intervertebral disc aging and degeneration: Involvement of the extracellular matrix. Spine, 29, 2691-2699.

[81] Saini, S, \& Wick, T. M. (2003). Concentric cylinder bioreactor for production of tissue engineered cartilage: effect of seeding density and hydrodynamic loading on construct development. Biotechnol Prog, 19, 510-521.

[82] Schaefer, D, Martin, I, Jundt, G, et al. (2002). Tissue-engineered composites for the repair of large osteochondral defects. Arthritis Rheum, , 46, 2524-2534.

[83] Solchaga, L. A, Penick, K, Porter, J. D, et al. (2005). FGF-2 enhances the mitotic and chondrogenic potentials of human adult bone marrow-derived mesenchymal stem cells. J Cell Physiol ,203, 398-409.

[84] Soukane, D. M, Shirazi-adl, A, \& Urban, J. P. (2005). Analysis of nonlinear coupled diffusion of oxygen and lactic acid in intervertebral discs. J Biomech Eng, 127, 1121-1126.

[85] Stockwell, R. (1971). The inter-relationship of cell density and cartilage thickness in mammalian articular cartilage. J Anat, 109, 411-422.

[86] Stockwell, R. A. (1991). Cartilage failure in osteoarthritis: relevance of normal structure and function. A review. Clin Anat, 4, 161-191.

[87] Trueta, J. (1963). Studies on the etiopathology of osteoarthritis of the hip. Clin Orthop Relat Res ,31, 7-19. 
[88] Tsutsumi, S, Shimazu, A, Miyazaki, K, et al. (2001). Retention of multilineage differentiation potential of mesenchymal cells during proliferation in response to FGF. Biochem Biophys Res Commun, 288, 413-419.

[89] Urban, J. P, \& Bayliss, M. T. (1989). Regulation of proteoglycan synthesis rate in cartilage in vitro: influence of extracellular ionic composition. Biochim Biophys Acta, 992, 59-65.

[90] Urban, J. P. G, Hall, A. C, \& Gehl, K. A. (1993). Regulation of matrix synthesis rates by the ionic and osmotic environment of articular chondrocytes. J Cell Physiology, $154,262-270$.

[91] Urban, J. P. G. (1994). The chondrocyte: A cell under pressure. Br J Rheumatol, 1994; , 33, 901-908.

[92] Urban, J. P. G. (2000). Present perspectives on cartilage and chondrocyte mechanobiology. Biorheology ,, 37, 185-190.

[93] van Beuningen, H. M, Glansbeek, H. L, van der Kraan, P. M, et al. (1998). Differential effects of local application of BMP-2 or TGF-beta 1 on both articular cartilage composition and osteophyte formation. Osteoarthritis Cartilage, , 6, 306-317.

[94] van der Kraan, P. M, Buma, P, van Kuppevelt, T, et al. (2002). Interaction of chondrocytes, extracellular matrix and growth factors: relevance for articular cartilage tissue engineering. Osteoarthritis Cartilage, 10, 631-637.

[95] van Osch, G. J. V. M. van den Berg, W.B.; Hunziker, E.B., et al. (1998). Differential effects of IGF-1 and TGF $\beta-2$ on the assembly of proteoglycans in pericellular and territorial matrix by cultured bovine articular chondrocytes. Osteoarthritis Cartilage, , 6, 187-195.

[96] Venn, M, \& Maroudas, A. (1977). Chemical composition and swelling of normal and osteoarthrotic femoral head cartilage. Ann Rheum Dis, 36, 121-129.

[97] Verdier, M. P, Seite, S, Guntzer, K, et al. (2003). Immunohistochemical analysis of transforming growth factor beta isoforms and their receptors in human cartilage from normal and osteoarthritic femoral heads. Rheumatol Int, 25, 118-124.

[98] Wilkins, R. J, \& Hall, A. C. (1995). Control of matrix synthesis in isolated bovine chondrocytes by extracellular and intracellular pH. J Cell Physiol, 164, 474-481.

[99] Williams, G. M, Klein, T. J, \& Sah, R. L. (2005). Cell density alters matrix accumulation in two distinct fractions and the mechanical integrity of alginate-chondrocyte constructs. Acta Biomater, , 1, 625-633.

[100] Windhaber, R. A, Wilkins, R. J, \& Meredith, D. (2003). Functional characterisation of glucose transport in bovine articular chondrocytes. Pflugers Arch, 446, 572-577.

[101] Wu, M. H, Urban, J. P. G, Cui, Z. F, et al. (2008). Effect of extracellular pH on matrix synthesis by chondrocytes in 3D agarose gel. Biotechnol Progress, , 23, 430-434. 
[102] Ysart, G. E, \& Mason, R. M. (1994). Responses of articular cartilage explant cultures to different oxygen tensions. Biochim. Biophys Acta,1221, 15-20.

[103] Zhou, S, Cui, Z, \& Urban, J. P. (2004). Factors influencing the oxygen concentration gradient from the synovial surface of articular cartilage to the cartilage-bone interface: a modeling study. Arthritis Rheum, 50, 3915-3924. 